\title{
Determinants of External Debt: The Case of Malaysia
}

\section{Rabiatul Adawiyah Mohamed Rafik}

\author{
Submitted to the \\ Institute of Graduate Studies and Research \\ in partial fulfillment of the requirements for the degree of
}

\author{
Master of Science \\ in \\ Banking and Finance
}

Eastern Mediterranean University

December 2015

Gazimağusa, North Cyprus 
Approval of the Institute of Graduate Studies and Research

\section{Prof. Dr. Cem Tanova \\ Acting Director}

I certify that this thesis satisfies the requirements as a thesis for the degree of Master of Science in Banking and Finance.

We certify that we have read this thesis and that in our opinion it is fully adequate in scope and quality as a thesis for the degree of Master of Science in Banking and Finance.

Asst.Prof.Dr.Korhan Gökmenoğlu

Supervisor

1. Prof. Dr. Salih Katırcıoğlu

2. Assoc. Prof. Dr. Nesrin Özataç

3. Asst. Prof. Dr. Korhan Gökmenoğlu 


\begin{abstract}
Over the past 30 years, Malaysia's external debt has been on an increase, with the increase closely linked to a number of economic factors. The changing quantities and qualities of external debt have become a national concern. Data related to the changes in dependent and independent variables between 1970 and 2013 was used in the study. The model was tested for unit root tests, cointegration test, vector error correction model, and Granger causality test. The cointegration test indicates there is one cointegrating vector. Moreover, two out of the four expectations were met in a significant manner through the long-run relationships. The government manage to reduce external debt by increasing GDP. But, the government increases capital expenditure by increasing external debt. This goes against the economic theory. In order to sustain debt, a government should increase capital expenditure in order to repay external debt. In addition, the possibility of sustaining the debt can be contradicted due to the fact that recurrent expenditure is also relied on external debt. Hence, Malaysia should find an alternative to gain money for recurrent expenditure instead of taking it out of the external debt fund. Based on the four explanatory variables, it is clear that the Malaysian government rely on GDP for the repayment of external debt. Where else, Granger causality test showed that only uni-directional relationships exist between the variables. Lastly, it is adviced that nationwide adjustment in policies is necessary in order to align growth with improvement in the determinants of external debt.
\end{abstract}

Keywords: Malaysia, external debt, vector error correction model, causality. 


\section{ÖZ}

Geçtiğimiz 30 yıl boyunca Malezya'nın dış borcu bazı ekonomik faktörlere bağlı olarak artış göstermiştir. Dış borçlanma yapısında gözlemlenen değişimler milli bir sorun haline gelmiştir. Bu çalışmada kullanılan veri seti 1970-2013 yılları arasında bağımlı ve bağımsız değişkenlerde gözlemlenen değişimlerden oluşmaktadır. Oluşturulan modele birim kök testi, eşbütünleşme testi, vektör hata düzeltme modeli ve Granger nedensellik testi uygulanmıştır. Eşbütünleşme testi sonuçları en çok bir eşbütünleşme denkleminin varlığını göstermektedir. Elde edilen sonuçlara göre Malezya hükümeti GSYİH'deki artış yardımıyla dış borcunu azaltmayı başarmıştır. Fakat, dış borçlanmadaki artış nedeniyle sermaye harcamalarında artış gözlemlenmektedir. Bu sonuçlar ekonomik teori ile bağdaşmamaktadır. Bu nedenle Malezya cari harcamalarını dış borcu artırmadan finanse etmek için alternatif yollar bulmalıdır. Granger nedensellik testi sonuçlarına göre kullanılan değişkenler arasında tek yönlü nedensellik bulunmaktadır. Son olarak ülkenin dış borçlanma belirleyicilerini göz önünde bulundurarak dış borç politikasında düzenlemeler yapılmalıdır.

Anahtar Kelimeler: Malezya, dış borç, vektör hata düzeltme modeli, nedensellik. 


\section{TABLE OF CONTENTS}

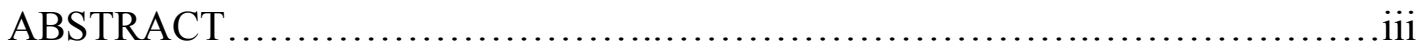

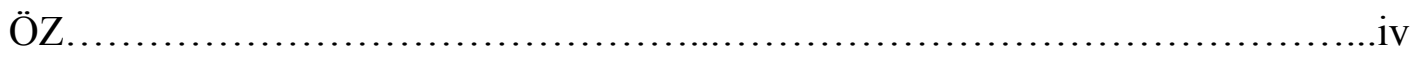

LIST OF TABLES ...................................................

LIST OF FIGURES .........................................................

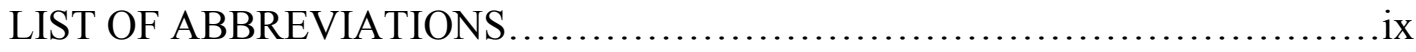

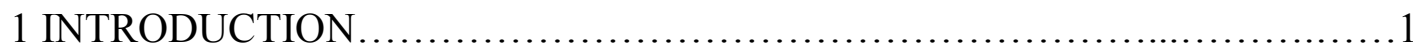

2 LITERATURE REVIEW ................................................ 15

2.1 External Debt............................................................. 15

2.2 Theories of External Debt and Economic Growth....................... 16

2.2.1 The Debt 'Laffer Curve' .............................................16

2.2.2 The Solow Growth Model...........................................18

2.2.3 Debt Overhang Hypothesis.....................................18

2.3 External Debt and Macroeconomics Risks.................................20

2.4 Debt Overhang and its Causes.....................................23

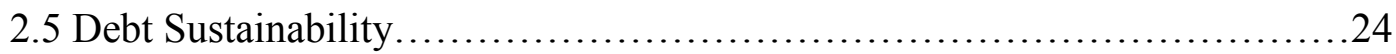

2.5.1 Sustainability Benchmarks.......................................25

2.5.2 Liquidity Benchmarks.......................................28

2.5.3 Fiscal Benchmarks...............................................29

2.5.4 Risk Management Benchmarks...................................30

2.6 Previous Empirical Studies on Determinants of Debt........................33

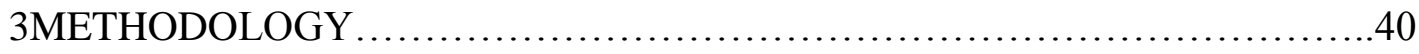

3.1 Data Description...............................................40

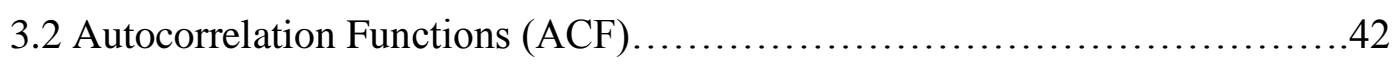


3.3 Unit Root Tests....................................................42

3.4 Cointegration Test..................................................45

3.5 Vector Error Correction Model.........................................46

3.6 Granger Causality Test............................................. 46

4 EMPIRICAL ANALYSIS AND DISCUSSION OF THE RESULTS.............48

4.1 Descriptive Statistics..............................................48

4.2 ACF and PACF Results.............................................. 48

4.3 Unit Root and Stationary Test Results...............................52

4.4 Cointegration Test Results.........................................54

4.5 Vector Error Correction Model Results.....................................55

4.6 Granger Causality Test Results....................................5 57

5 CONCLUSION AND RECOMMENDATION .............................59

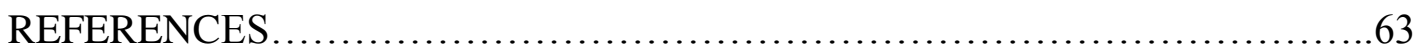

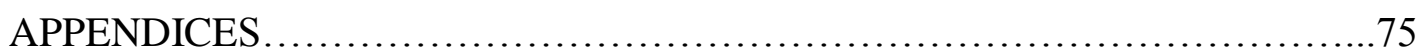

APPENDIX A: ACF and PACF ............................................ 75

APPENDIX B: Johansen Cointegration...................................... 76

APPENDIX C: Vector Error Correction Model..................................78

APPENDIX D: Granger Causality..................................... 80 


\section{LIST OF TABLES}

Table 1: Descriptive Analysis..............................................48

Table 2: ACF and PACF Results.............................................. 51

Table 3: ADF, PP Unit Root and KPSS Stationary Test Results.................53

Table 4: VAR Lag order selection criteria results.............................54

Table 5: Cointegration test results.......................................54

Table 6: Normalized cointegrating coefficients results.........................55

Table 7: VECM results...................................................56

Table 8: Granger causality test results....................................57 


\section{LIST OF FIGURES}

Figure 1: Malaysia's External Debt...........................................

Figure 2: Time Series of Variables under Natural Logarithm...................49 


\section{LIST OF ABBREVIATIONS}

$\mathrm{ACF}$

ADB

ADBI

ADF

AIC

$\mathrm{BN}$

CEXP

ED

EXR

GDP

GNP

HIPC

HQ

IMF

KPSS

LDC

LIBOR

NEP

NPV

OAP

OECD

OLS

PACF
Autocorrelation Function

Asian Development Bank

Asian Development Bank Institute

Augmented Dickey Fuller

Akaike Information Criterion

Barisan National

Capital Expenditure

External Debt

Exchange Rate

Gross Domestic Product

Gross National Product

Heavily Indebted Poor Countries

Hannan-Quinn Information Criterion

International Monetary Fund

Kwiatkowski, Phillips, Schmidt and Shinn

Less Developed Countries

London Interbank Offered Rates

New Economic Policy

Net Present Value

Old Age Pensioner

Organization for Economic Cooperation and Development

Ordinary Least Square

Partial Autocorrelation Function 
PP

PPP

PV

REXP

SC

US

VAR

VECM
Phillip Pheron

Public Private Patnership

Present Value

Recurrent Expenditure

Schwarz Information Criterion

United States

Vector Auto Regressive

Vector Error Correction Model 


\section{Chapter 1}

\section{INTRODUCTION}

The definition of total external debt indicates that it is finances owed to non-residents and accrued payment can be done through supply of goods, services or foreign currency. The debtors can be the government, companies, or citizens of that country. The lenders can be foreign governments, foreign commercial banks, or international financial institutions. External debt is composed of long-term debt that is guaranteed by public and private entities (some of which do not bear any guarantees), short-term marketable debt instruments, and and loans by multinations such as the IMF (International Monetary Fund (Ali \& Mustafa, 2012)). Liabilities include both principal and interest.

As part of the financing sources for national development, external debt has contribute extensively in the economic growth in both developed and developing countries. As part of the future development, a country can invest in projects with long-term returns, even when the resources are not available domestically. For most of the least-developed countries, the primary challenge exists in the acquisition of the initial capital requirements, even when the net present value indicates the viability of the project (Collignon, 2012). External debt is key in developing international relations and facilitating global interdependence. Developed countries have the opportunity to contribute to the growth of developing countries, while expanding the market for its industrial products and services. 
There are several characteristics common to most developing countries. Developing countries face the challenge of curtailing sociopolitical challenges, especially corruption. Although corruption is a global problem, its influence in growing economies is more pronounced than in other kinds of economies (Bullow \& Rogoff, 1989; Rahman, 2012). Developing countries have challenges in prioritizing development plans and strategies. Resource availability and lack of appreciation for the opportunity cost of timing the development project can negatively impact prioritization (Atique \& Malik, 2012). These strategies can also be negatively impacted by the failure on the part of planners to implement synergistic and symbiotic projects that optimize returns in the long run (Atique \& Malik, 2012). Developing countries lack the necessary manpower and skilled personnel to plan, implement, and maintain certain projects that are essential to national growth. The lack of sufficient resources to fast-track economic growth plagues most developing countries (Ezeabasili, Isu, \& Mojekwu, 2011). Despite these challenges, developing countries must solve financing problems in a way that allows them to sustainably grow.

External debt plays a significant role in economic development across economies. If a country's public savings ratio is less than required investment, then the country will have to acquire additionally to finance its desired level of economic development (Michael \& Sulaiman, 2012). Along with the acquisition of additional resources for urgent and time-sensitive projects, external debt facilitates the spread of risk across a longer period. For a large-scale project, external debt is an alternative approach to reducing the real cost since a government can defer repayment of external debt. The government, in this scenario, relies on returns from the project to supplement the 
existing allotments for reimbursement of the debt. External debt introduces technology sharing, skill transference, and competency building. Many nations prefer to acquire skills from the international market place; thus, it is possible for a country to benefit from the globally-acknowledged standards. Due to limited resources in national economies, external borrowings have developed to the principal foundations of capital (Schclarek, 2004). Nevertheless, external debt remains a precious resource for the developing countries to break the vicious cycle of being poor.

External debt may also create problems for developing countries. Failure of the developing countries to match growth with returns compromises the sustainability of debt financing, particularly for projects that have social returns. Failure of developing countries to deploy adequate resource management capabilities can lead to challenges in repayment of external debt, which can be exacerbated by poor economic and financial returns. In addition to these factors, accumulation of external debt over a certain threshold can create problems for the sustainable macroeconomic fundamentals as well. Past events have increased international trepidations about the possible negative outcomes of the extensive debt increase of developing countries. The debt overhang in the early 1980s of countries like Mexico and Argentina contributed to this fear.

The challenge of sustainability in debt is not restricted to developing countries. The aftermath of the economic crisis in 2006-07 left most countries in Europe, as well as America, with significant challenges stemming from weakened financial systems (Arestis \& Sawyer, 2009). More recent concern about impending systemic financial crises, fueled by mounting external debts of some of the member countries, has 
spread across countries in economic blocs like the European Union (e.g., Ireland, Spain, Greece). In addition to a liquidity crisis, the inability to access debt financing and service existing debt resulted in economic meltdowns (Dyson, 2014). It is widely accepted that external debt may contribute to economic growth if it is utilized efficiently and effectively. However, it is also widely held that above a certain threshold of external debt can become detrimental to economic fundamentals, especially economic growth. In sum, sustainability of external debt and the consequences of accretion of external debt on economic growth and investment in a country are commonly lingering questions of concern for policymakers and academicians alike (Ali \& Mustafa, 2012).

The disparity in results from the sustainability of external debt in developed and developing countries has spurred intensive research. Characteristics of the target country, features of its financial system, and factors of the country's macroeconomics influence the sustainability of external debt. There remains no consensus on the sustainability of external debt, much less the relationship between external debt and other macroeconomic fundamentals. This lack of consensus deserves further attention.

Malaysia, as one of the Asian tigers, has used external debt as a measure to achieve one of the most successful macroeconomic performances among all developing countries. The success of the country in growth and development has grabbed the attention of the world and of researchers (Athukorala, 2010). Most of the success in the $20^{\text {th }}$ century was attributed to the affirmative action program referred to as the New Economic Policy (NEP). The program was adopted in 1971 and aimed to 
transform Malaysia into an industrialized country. Under the program, the country focused on comprehensive poverty reduction projects and restructuring of the employment system. The new employment system was designed to redistribute and re-engineer disposable income to eliminate disparities. Malaysia's government prescribed ratios of enthnicities into business ownership and management, essentially reinserting historically disenfranchised groups into all levels of the economy. Also, in order to attract foreign investment, the country developed free trade agreements that sought to attract foreign direct investments as early as 1980. Success was reported as early as 1990, which was 20 years after the implementation of the NEP (Carter \& Harding, 2010). Based on these policy strategies, the country experienced an average growth rate of $11.1 \%$ between 1996 and 2005 with regard to exportoriented manufacturing activities. The total annual growth in exports over the same period was higher $(11.1 \%)$ than imports (10.4\%) (Kumar, 2015). Most Malaysian industries experienced double-digit growth rates per annum. With a per capita income of US $\$ 3540$ in 2003 , the country was ranked third among the top developed countries in South East Asia (Carter \& Harding, 2010).

Malaysia's economic performances are appreciated by the international community and the academic world. However, the country experienced two severe financial downturns, each of which followed a long period of strong growth performance. In the eight years preceding the 1997 Crisis Malaysia reported a 4\% inflation rate and 8.9\% GDP growth, with the primary focus on expansion of manufacturing (Ariff \& Abubakar, 1999). The targeted growth rates sought to elevate the country to a developed economy by 2020 . However, the country was hit by a severe financial crisis in 1997. It has been reported that the crisis was not managed well. The 
sustainability of the intervention measures failed due to the significant downward pressure coupled with a reduction in the foreign capital inflows. The restriction on trading the Malaysian currency (Ringgit) and restriction of the capital flows out of the country set up a dangerous situation. This combination of restrictions made it possible for manipulation of the Ringgit's value without the induction of market forces to stabilize the value and introduce sustainability for the future. Most of the intervention measures were either ill timed or disproportional to the crisis. Consequently, a wide range of domestic loans were classified as nonperforming, with most institutions deregistered. Following the $1997 \mathrm{crash}$, which was part of the larger Asian Financial Crisis, Malaysia lost $50 \%$ of its gross domestic product (GDP; Athukorala, 2010). At the worst point of the downturn, the price of the Ringgit fell by $50 \%$ against the US Dollar.

Following the crisis, the recovery measures were insufficient in generating the necessary economic momentum to reverse the crisis. The combination of exogenous and endogenous effects on the domestic currency introduced limitations to Malaysia's central bank. At the time, the bank was in the process of capitalizing the discounted toxic assets from the existing institutions. Most of the recovery measures were terminated in 2005 when the country achieving its first trade surplus of US\$14 billion (Zakaria et al., 2010). To this day, most of the toxic assets have not yet achieved the precrisis value, because investor confidence was dampened by the effects of the subsequent crisis in 2008-09. The country experienced a reduction in GDP, domestic currency value, and the ability to attract foreign direct investment over the four intervening years between the end of recovery measures and the 200809 Crisis (Hassan, 2002). Concurrently, the fixed exchange rate based on the US 
Dollar implied that most of the domestic economic policies and investments were influenced by fluctuations in the US Dollar.

It is noteworthy that the recovery was financed with structures and frameworks that perpetuated the foreign debt of the country. The acquisition of smaller banking institutions in order to avoid collapse was a fundamental move towards recovery. The purchase of financial institutions was financed through domestic and foreign debt, with foreign debt terms representing highly restrictive terms. The Ringgit was pegged to the US Dollar in September 1998 (3.8 Ringgit to the US Dollar) implying that, in addition to fluctuations in the Ringgit, any changes in the US Dollar were bound to influence the outcome of the recovery (Athukorala, 2010). Before this pegging of the Ringgit, the interbank rate increased from $7.8 \%$ in 1996 to $11 \%$ in 1998 and then fell to $3 \%$ in 1999. Consequently, the most damaging effect of pegging the Ringgit to the US Dollar was the replacement of domestic debt and earnings from domestic production with foreign debt (Zakaria et al., 2010).

A decade later in 2007, Malaysia was hit one more time by a severe economic crisis. In the most recent meltdown, Malaysia saw capital markets lose $20 \%$. The extensive effects of the recent crisis originate from the fact that massive capital outflow followed in 2009, with over US\$6 billion lost. The absorption of the losses and capital increased exposure to debt collaterals at a time when Malaysia depended highly on export trade to achieve development goals. Similar outcomes were experienced due to changes in commodity prices, with crude oil losing $50 \%$, palm oil dropping 30\%, and rubber prices losing 57\%. Manufacturing for export contracted by $15 \%$ in 2009 , which created a massive loss to the country due to quantity and quality 
of outputs. In response, overnight banking rates and stimulus packages were reduced, which intensified the government's focus on external debt even though access to capital was limited.

This history has led to one of the most pressing problems of the current Malaysian economy, which is its external debt. There are concerns about the sustainability of Malaysia's trend of the last two decades to increase its external debt. Malaysia's economy has displayed a rise of total accruing external finance (Figure 1), which has brought to the fore issues of the applicability of external financing to accelerate he economy. Based on Figure 1, it is clear that significant changes in the amount of external debt in Malaysia were reported post the 2008-09 Crisis.

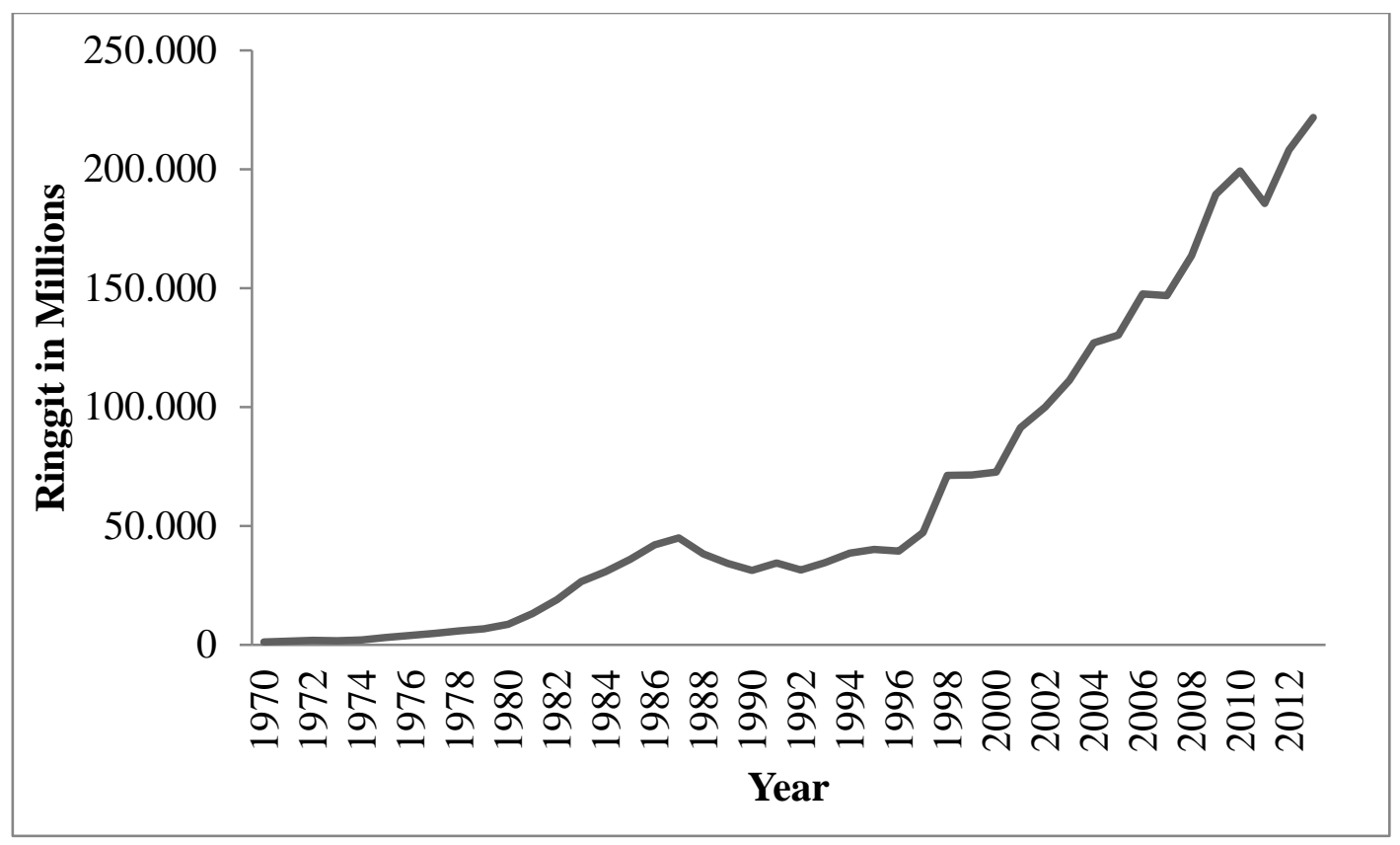

Figure 1: Malaysia's external debt.

One way countries avoid the overreliance on this source of capital is to establish a debt ceiling, which guides policies at the national level. As indicated by Arnone, 
Bandiera, \& Presbitero (2010), the existence of a debt ceiling provides guidance on the maximum amount of debt that can be acquired at any time. It is designed as an increment amount, aggregate amount, or both. The oversight bodies in Malaysia's economy have wondered whether the debt ceiling enforces fiscal discipline (Loganathan, Sukemi, \& Sanusi, 2010). This is worrying as the statutory ceiling has been raised multiple times by the Barisan National government $(\mathrm{BN})$ over the past decade to legalize the federal debt level, which has been increasing faster than the GDP (Investment Frontier, 2013). The ceiling rose from a limit of 40\% (excluding Shariah) in April 2003 to 45\% in June 2008 to 55\% in July 2009. However, unlike the US where the debt ceiling has also been raised many times in the past decade, Malaysia's limit is not legally binding and is discretionary to the Minister of Finance (Investment Frontier, 2013).

In discussing debt sustainability issues, it is common for analysts to harp on one key benchmark: the debt to GDP ratio. Empirical findings showed that if debt-to-GDP ratio is equal or exceeds the $90 \%$ benchmark level, public debt would definitely hinder economic growth (Reinhart \& Rogoff, 2010; Bivens \& Irons, 2010). Malaysia's debt-to-GDP ratio is 50\%, which doesn't surpass this threshold. Over emphasis on the debt-to-GDP measure alone can be misleading, because a country could pile up unknown risks outside of this ratio and destabilize the country (The Malaysian Insider, 2015).

Malaysia was selected as the country of focus for this research because it is a developing country that has achieved mixed success and challenges with the utilization of external debt. In the recent past, the country has experienced a mean 
growth of $6 \%$ in its GDP and several challenges to the sustainability of this growth. There are also concerns about the future of its sustainability of external debt. As a result, Malaysia provides an excellent subject for study on the connection between external debt and macroeconomic variables.

Sustainability of external borrowings is one of the most significant national concerns, especially for the under-developed countries. There are many factors that affect sustainability of external debt. Its composition, rate of increase, government policies regarding external debt, and institutional policies (e.g. transparency) are important factors that affect the relationship between determinants of external debt and sustainability of fiscal policy. Given the complicated relationships between external debts and macroeconomic variables, investigations of the macroeconomic determinants of external debt may shed light on the important factors of the sustainability of it. This research analyzes the impact of several macroeconomic variables on external public debt and provides information on which of those variables contribute to the external debt's sustainability.

This research looks into the impact of macroeconomic indicators on external debt for the period of 1970 to 2013 . The model is specified as follows;

$$
\mathrm{ED}=\mathrm{f}(\mathrm{GDP}, \mathrm{EXR}, \mathrm{REXP}, \mathrm{CEXP})
$$

where:

$\mathrm{ED}=$ External debt,

GDP $=$ Gross domestic product

$\mathrm{EXR}=$ Exchange rate, 
REXP = Recurrent expenditure,

$\mathrm{CEXP}=$ Capital expenditure

GDP is the aggregate output in a country. An increase in the GDP results to decrease in external debt due to the existence of domestically-generated financial resources for utilization in expenditure. The linear relationship originates from the existence of alternative to debt in the form of finances generated from export oriented production. In addition to enhancement in the productivity of the national economy, the country is able to acquire revenues from fiscal policies such as taxation (Memon Rus \& Ghazali, 2014). However, it is also possible for increase in GDP to propagate an increase in utilization of external financing. If a nation must access to affordable debt in comparison with the revenues from the debt-financed projects, then external debt becomes a viable source of financial capacitation. Although this is practically viable at the firm level, it is also applicable at the country-level (Memon Rus \& Ghazali, 2014).

Based on the movement in the foreign exchange rate, it is possible to define the competitiveness of the domestic currency in the global market. The study by Benedict, Ehikioya \& Asin (2014) indicated that countries with a strong currency tend to inverse relationships with the level of indebtedness. A strong currency indicates strength in economic indicators and the participation in export oriented production (Awan, Anjum \& Rahim, 2015). The authors indicated that the exchange rate is a statistically significat determinant of external debt. Strong currencies originate from extensive participation in global markets, especially a strong balance of trade. The increased demand for currency in the global market results in 
strengthening of the currency's value. As a result, Meesook (2001) indicated that the exchange rate provides intrinsic indications of the stability and strength of an economy, since it affects the competitiveness of the currency in international markets. A weaker currency implies that a country has to source additional financing in order to participate in international trade and domestic expenditure.

Recurrent expenditures represent the standing destinations for state funds. These expenditures are a significant proportion of the country's budget. The constant nature of the appropriations for these expenditures implies that most of the revenues available to the government are directed toward financing recurrent expenditures (Ribiero, Villafuente, Baunsgaard, \& Richmond, 2012). The recurrent nature of these expenditures underscores the importance of them. As a result, it is common for countries to borrow in order to finance recurrent expenditures. these recurrent expenditures are part of the total financial commitments of the government, and they represent yearly expenditures at the national level.

Lastly, capital expenditures financed through external debt are key in determining the level of investment in the provision of services and amenities to the citizens (Awan, Anjum \& Rahim, 2015). In most developing countries, the budgetary requirements for capital expenditure are restrictive. In addition, the lack of expertise and knowhow results to reliance on external finance and human resource to implement these expenditure. A study by Khan \& Villanueva (1991) stated that countries with an increasing amount of external debt comprehended such problem by increasing the investment ratios. In some instances, the providers of the industrial components rely on financing structure that include debt components in order to 
make the investments viable for developing countries. Investment in capital expenditure is based on necessity and viability of returns. They are singular investments requiring intensive capital outlays, and they sometimes require maintenance expenditure and sustainability investments. As part of the integral investment in infrastructure and other necessities, governments require significant capital to actuate such goals (Ribiero et al., 2012).

As a result, the assessment of the changes in GDP, exchange rates, recurrent expenditures, and capital expenditures presents a balanced view of the changes in the economic outlook of Malaysia. Therefore, these factors will be used to investigate the relationship with external debt.

The empirical investigation uses several approaches. First descriptive statistics are reported. The use of unit root, Johansen cointegration, vector error correction model, and Granger causality will test the relationship among the variables. The unit root tests evaluate whether variables in the time series data are stationary under an autoregressive model (Maddala \& Kim, 1999). The tests for stationarity targets to determine the effects of the properties and behavior of the data. If stationarity is not proven, this means that the assumptions of asymptotic relationships are nonexistent. As a result, since the assumption of t-distribution for t-ratios does not hold, hypothesis testing for regression parameters will not be valid (Choi, 2015). The cointegration tests focus on testing regression when nonstationarity is indicated through the unit root tests. The cointegration tests seek to establish the effects of a adjustments in the independent variables on the dependent variable (Maddala \& Kim, 1999). In the current study, the Johansen cointegration test shall pe applied. The 
vector error correction tests will be employed to interpret short- and long-term results (Maddala \& Kim, 1999). Eventually, the Granger causality test shall be applied to test the existence and trend of the causal relationship in the pairs of the variables. Causality tests determine whether the change in one variable accounts for more future change in the other variable. The Granger causality test will indicate the direction and magnitude of the change.

This paper has policy implications for decision-makers, "and technocrats in the country. Additionally, the results sourced from the relationships between external the two categories of variables would be valuable for formulation of policies. This paper could give insights about the capacity of a nation to fulful its future debt obligations to creditors during the lending process.

The next chapter reviews the empirical and theoretical literature on the thesis. Chapter 3 provides an outline the data collection and methods of analysis while the empirical analysis and findings are presented in chapter 4 . Chapter 5 offers a conclusion for the paper and offers recommendation. 


\section{Chapter 2}

\section{LITERATURE REVIEW}

This section provides a review of the existing literature on the determinants of external debt in the under-developed countries is studied. Theories on external debt, determinants of economic change and external debt as well as empirical findings from past studies will be discussed in this section.

\subsection{External Debt}

According to Shabbir (2009), external debt is described as a ratio of the national debt owed to foreign financiers. Past studies have classified debt as either reproductive debt or deadweight debt. Reproductive debt is when a debt has assets to balance it. For example, reproductive debt would include money borrowed for building power plants, airports, factories, etc. However, debt that is acquired to fund war and recurrent expenses are deadweight debts (Oke \& Boboye, 2012). External debt is quite different from domestic debt as it poses its own peculiar risks and rewards. One key risk area is that since external debt is billed to nonnationals, it must be reimbursed primarily in peregrine currency, products, or administrations. This reimbursement is greatly affected by the debtors' trade balance and exchange rate volatility. Ajayi (1991) warned that if the magnitude of the external debt of the trade balance is vast, it may possibly put strain on the economy. Consequently, the primary reward a debtor country gains from external debt is the very low interest rate on debt compared to her domestic economy. 


\subsection{Theories of External Debt and Economic Growth}

Theoretical models on foreign debt provide a theoretical relationship between debt sustainability and change of debt, and the commensurate effect of those factors on economic growth. The theoretical perspective provides guidance regarding the optimal amounts of debt that propagate financial growth in a country. The explaination for the direction taken by Malaysia with regard to economic growth and utilization of economic debt, theories on economic debt shall be discussed. The theories provide links between the variables associated with external debt and economic performance. The theories provide evidence-based backing from past studies, theoretical models, and current assumptions. However, the uniqueness of Malaysia and changes in the past can only be tested through data analysis that will be tested in later sections. The findings from the analysis will be used to confirm or reject the implications of various theories discussed below.

\subsubsection{The Debt 'Laffer Curve'}

The model indicates that countries with larger stocks of debt, whether external or internal, have a higher chance of failing to repay or service the debt (Pattillo, Poirson, \& Ricci, 2004). The Laffer curve is an explanation of the debt overhang hypothesis, and it theorizes that a curve indicates the optimal level for each country's debt. Once the quantity exceeds the optimal amount that the country can service, the ability to repay the debt drops significantly. Theoretically, the highest point at the Laffer curve represents the stage where external financing becomes a tax on the country's investments and a hindrance to economic policies.

External debt imposes upfront and auxiliary costs of economic systems. At the point where the tax burden exceeds the amount of revenue generated, the debt displays 
signs of inverse marginal effects on growth and development. The debt overhang model fails to analyze the outcome of growth directly, and it focuses on the quantitative aspects of the debt. The model is clear on the incentive effects of debt, since a rise in the debt amount causes a lessening in the ability to implement reforms that focus on economic growth and efficiency. The most common strategies become less viable under excessive amounts of debt, and these strategies include fiscal adjustments and liberalization of trade. They become less viable, because they compromise the ability of the government to acquire revenues from trade and production (Arnone, Bandiera, \& Presbitero, 2010).

The use of the Laffer curve was tested using discounted cash flows and debt amounts from the World Bank Data (Pattillo, 2002). The tests accommodated the assumption that interest rates for external debt are lesser than market rate. Most countries rely on the nominal terms when assessing the ratio between GDP and export, and it becomes necessary to provide context for these terms by accommodating the future value as well. After accommodating the crowding out effects of debt resources due to servicing the debt as opposed to channeling economic growth, it was realized that an upturned ' $u$ ' link existed between external debt and economic growth. Incremental debt slows growth down eventually, even if the overall growth in debt is beneficial or necessary to the country.

When quantitative elements are included in the debt, it is clear that the negative outcomes are more clearly seen when the total contribution of debt to economic growth is specified (Pattillo, Poirson, \& Ricci, 2004). When the debt exceeds the 35- 
$40 \%$ threshold in comparison with the net present value of the GDP and exceeds $160 \%$ of the exports, the inverse marginal relationship becomes apparent.

\subsubsection{The Solow Growth Model}

The model, also referred to as a neoclassical growth model, is key in explaining the properties of exterior debt on macro and microeconomic growth. The propositions of the model are based on the findings by Mankiw et al. (1990) who theorized that households determine the savings and investment/expenditure ratios based on the prevailing conditions (Akram, 2015). When public debt is high, the government redistributes the debt burden through changes in taxation. When the Cobb-Douglas model of human capital is integrated, it is possible to determine the effects of the increase in taxation on production as well as consumption. The external debt dynamics present a challenge to a government, implicating the need for fiscal and monetary policies that affect interest rates, government borrowing and expenditure as well as budgetary deficits. As a result, the steady growth in the country is inversely related to changes in external debt when the contribution by physical and human capital peaks (Babu, 2014). When the growth rate of productivity and costs of borrowing equates, then a country is bound to experience a negative outcome due to the presence of external debt.

\subsubsection{Debt Overhang Hypothesis}

The hypothesis outlines that when the level of indebtedness is high, it discourages investment and adversely infleunces growth as prospective higher tax rates are set to repay the debt (Ali \& Mustafa, 2012). Moreover, a high level of external debt increases a country's probability of default. Fears that stem from opinions that national deficits ultimately could be monetized thus leading to inflationary pressure. Elmendorf \& Mankiw (1998) reiterate that a nation that has massive debts has a high 
likelihood of facing singificant high rates of interest, with resounding pressure on the monetary policies by other countries or the country's own citizens to attempt the reduction of the rates through expansionary policy. The approach has the ability to achieve reduction of the interest rates in the short-term but will have no direct effect on the real interest rates, while emergence of inflationary tendencies and nominal interest rates in the long run (Rahman, 2012). On the other hand, often economic managers would not want to concede macroeconomic stability by production of more notes and fluctuation in the taxes. These actions may lead to inefficiency, revenue loss, and economic uncertainty. The only open opportunity that the nation can adopt becomes the debt option (Atique \& Malik, 2012; Ezeabasil et al., 2011). Since foreign borrowing provides capital at interest rates lower than that of the home country, external debt looks more appropriate and compulsory to hasten economic growth. External debt can help a country attain those accomplishments, provided that the country is directed to growth of the the productivity of the economy to achieve targeted growth rates. Hence, the deployment of funds and the proceeds against the charges on the debt are essential in determining the outcome. Therefore, if the mation acquires investments in infrastructure, the invested funds have the ability result to faster growth and socioeconomic development (Ogunmuyiwa, 2011).

Nonetheless, debts have to be repaid. Funds borrowed are merely postponed taxation. Were (2001) advised that high borrowing from overseas is not directlyrelated to reduction in the economic growth, but rather implies that a country may be unable to meet its debt obligations. Failure to service debt on time increases a country's risk profile. It introduces difficulties for under-developing countries to acquire new debt at viable rates and less conditions from multilateral agencies. At the other end, debt 
repayment is a signaling stratagem to disclose the capability of the nation and can exhibit the rudiments of the state's economy (Sandleris, 2008).

\subsection{External Debt and Macroeconomic Risks}

Experts are of the view that the steep public obligation may result in fiscal and monetary emergencies (Okosodo \& Isedu, 2011). In the event that a nation is facing a pattern of an expanding civic obligation, lenders may be agonizing over the abilities of that state to administer new obligations (Bivens \& Irons, 2010). The impact of this situation will be that a lender requests higher premium percentage as a well-being allotment for them to continue funding new shortfalls. Consequently, an increase in annual percentage rate can misrepresent the proportion of the financial structure and could frame a budgetary emergency. Bivens and Irons (2010) opined that this would be the case if the percentage of open obligation to GDP was higher than the $90 \%$ threshold. Furthermore, it is reported that countries with more than $60 \%$ external debt-to-GDP ratio experienced a GDP weakening in growth rate per annum by $2 \%$ (Reinhart \& Rogoff, 2010). This is because the debt is defined in foreign currency, which fluctuates due to conditions in creditor countries. Contrarily, others establish that soaring public obligation does not injure the economic movement, particularly in modern economics (Panizza \& Presbitero, 2014).

Arnone et al. (2010) discussed the liquidity constraint as referenced by Pattillo (2002). By definition, the liquidity constraint is the adverse effect of economic growth due to debt through limitations and access to cash flows due to the need to service the debt. These payments crowd out public resources and investments, thus resulting in excessive debt obligations that affect investment decisions (Pattillo et al., 2004). The need to reschedule payments and channel funds to service nominal debt 
obligations becomes a standing cash outflow that reduces the validity of exports and other fiscal aspects. When combined with the effects of uncertainty in the future with regard to cash flows and attractiveness of investments, the burden becomes even larger. Some external debts are laced with direct and indirect cost of change (Okosodo \& Isedu, 2011). Thus a country with higher debt pays more direct and opportunity costs due to the possibility of volatility in returns. The sustainability of payment becomes a challenge when fundamentals are adverse.

Fiscal expenditure decisions relate to the utilization of governmental revenues originating from taxation (Ali \& Mustafa, 2012). In addition to the policies by the government, the extent to which fiscal expenditures contribute to growth is dependent on tax structures in place. Aggregate demand and supply levels are also important, since they influence the entirety of corporate taxes. In most countries where income tax is utilized as a fiscal tool, disposable incomes, and wage rates are also key determinants of fiscal expenditure (Shabbir, 2009). The primary approaches include subsidies, investment in infrastructure, and social protection for the aged.

Various Asian administrations uphold huge cost subsidy projects to assist belowmarket customer costs for her citizens, especially for food and energy (Stanescu, 2013). Subsidization involves expenditure to reduce the direct costs of certain goods and services in circumstance where the public cannot afford the market prices. When subsidies are applied, it implies that the government is spending funds that have long term effects, especially for basic needs. A similar scenario exists in infrastructure development as indicated by Hayati (2012). Fast-track development of Asian economies requires considerable interests in infrastructure not only to keep pace with 
financial extension, but also to bolster more elevated amounts of profitability (Hayati, 2012). Malaysia is no exception. The Asian Development Bank and the Asian Development Bank Institute (ADBI \& ADBI, 2009) evaluated that aggregate substructure needs in Asia from 2010 to 2020 would add up to $\$ 8.3$ trillion (The Malaysian Insider, 2015). Vitality-related spending makes up about 50\% of the aggregate, and the second biggest need is for transport. On the other hand, open framework spending plans can just cover a small amount of the venture expense. Lastly, spending to accommodate the needs of the aged is another concern, since the benefits are not direct. The aging trends in Malaysia are relatively subdued compared to Japan, Korea, or Singapore (Morgan \& Kawai, 2013). However, the consolidated impacts of higher wages and mature populace are likely to prompt a quick ascent in social segment spending in Asian economies in the nearing decades. Edes and Morgan indicated in 2014 that an aging population is closely linked to a reduction in productivity, creativity, and competitiveness in the global markets. A wide range of social spending by the government targets sustainability elements as opposed to revenues and returns, which generate investments. Consequently, if a large proportion of debt is committed to such investment, the lack of a balancing source of national income results in difficulty managing the debt (Shakar \& Aslam, 2015). The general perception is that debt financing for social expenditure places a country in a challenging economic position, regardless of the beneficiaries. If the younger generation is targeted to benefit from the social expenditure, the long-term perspective of the returns from the investment introduces risk aspects that compound the range of challenges facing the country. Expenditure on the aging population results in savings rather than revenues, just like in the case of subsidies and infrastructural development. However, subsidies and infrastructure development 
have measurable benefits in terms of returns, as opposed to expenditure on old age pensioners (OAP; Morgan \& Kawai, 2013). The expenditures become necessary as approaches to enhancing the quality of life of OAPs becomes important, as well as reducing the costs of managing their needs at the household levels. Due to the lack of direct benefits, the level of these appropriations depends on the economic ability of a country. Consequently, it is imprudent to invest funds sourced from domestic or foreign debt, since returns to scale are not assured (Shakar \& Aslam, 2015).

\subsection{Debt Overhang and Its Causes}

Krugman (1988) characterized it as a circumstance where the predictable reimbursement of the foreign debt misses the mark concerning the prescribed estimation of the finance. After analysis of debt overhang's effects on the Phillipines, Borensztein (1991) characterized debt overhang as a circumstance in which the debt holder nation receives almost nothing of the profits of any extra venture due to debt service obligations, and Borensztein concluded that debt outcropping had an antagonistic impact on isolated interest.

The dilemma of debt accumulation in singular product economies has been principally associated with external influences (Athukorala, 2010). These external influences affect the country's response to world oil value shocks, protectionist trade policies, and extravagant liberal loaning arrangements of global business banks. Though these external complications do not act alone, they are aggravated much of the time by inside components because of macroeconomic strategy mistakes. Two of such lapses are connected with monetary flippancy and conversion scale misalignment (Ajayi, 1991). 
In many situations, the debt overhang has been used to clarify the phenomenon that a country's responsibility of external obligation has increased over time to become unendurable. This phenomenon has brought worries regarding the damaging impacts of debt on financing and development to the forenfront, which is considered the debt overhang effect. Kumar, McLambo, \& Savvides (1996) documented that debt service had a negative relationship to economic growth, demonstrating that the theory of debt overhang effects is most likely a real phenomenon. This new way of thinking about the debt overhang may explain why many less developed countries' (LDC) large debt accumulations in the past resulted in debt overhang, which discouraged investments and negatively affected future output.

\subsection{Debt Sustainability}

Debt sustainability is characterized in two straightforward aspects. First, financial debt sustainability implies that a nation has the capacity to administer its debt. Secondly, a nation's debt service does not repress development and general economic strategy.

The research of Greene \& Villanueva (1991) included twenty under-developed countries from 1975 to 1987 , and they discovered the proportion of debt to GDP and debt service balance meaningfully and undesirably influence private venture. This unlocked an important query about whether a miniscule open economy like Malaysia's would be susceptible to the debt's negative effect. According to Reinhart \& Rogoff (2010), debt benchmarks of developing markets in the season of nonpayment were averaged from $41 \%$ to $60 \%$ of GNP. However, the debt limits in Malaysia appears sensible at a total sheer external debt of $29 \%$ in June 2013. This is sustainable in terms of debt management. 


\subsubsection{Sustainability Benchmarks}

The key standout perspectives of prospecting is to check whether the proportion of finance is manageable in any event in the mid-term time period (Clements, Bhattacharya, \& Nguyen, 2003). Similar to what is seen in some studies, an extensive variety of quantitative pointers could be used to support the entire system of financial and monetary obligation. Quantitative pointers could also help support stocks in comparison to flows (debt service) as numerator, as well as exports, GDP, and economic revenues for the denominator.

It is wise for the nation's obligation office to recognize that an arrangement of benchmarks could guarantee obligation supportability in the intermediate range and keep the national macroeconomic approach targets in view (Loganathan et al., 2010). In wider terms, this could indicate that the status of debt at any stage in time is homogeneous with the inclusive macroeconomic objectives such as upholding a steady debt-to-GDP ratio, encouraging growth and investments, and sustaining sufficient external sustainability.

Over the long run, there have been different recommendations and international limits used to evaluate the debt manageability of low-income nations (Atique \& Malik, 2012; Edo 2002). Debt viability was typically assessed by utilizing the proportions of debt stock to GNP and by taking into account exports and debt service to exports before the presentation of the HIPC in 1996. Despite the fact that the World Bank frequently distributed the ranges it used to characterize nations as extremely or modestly indebted, these ranges did not take into account each country's macroeconomic characteristics. The World Bank's ranges were based on 
three-year average numbers of Present Value (PV) of debt-to-GNP ratios or Present Value of debt-to-export ratios for merchandise and all services (Sandleris, 2008). Nonetheless, there were no globally concurring benchmarks for deciding sustainability (Sandleris, 2008).

While there is no general guideline that identifies the thresholds to debt viability, it can still be assessed and surveyed by applying a combination of scales. As the first maintainability indicator, the proportion of debt service installments (interest rates and principal) to the estimations of export of commodities and amenities is an indicator of how the nation's export revenues will be separated into the amounts that offset external debt. Second, obligation load as a maintainability indicator can be calculated as the proportion of premium installments to the profit in exports of products and administrations. Obligation load also demonstrates how much of the present profit is needed for a country to benefit from the financial obligation (Murad \& Aziz, 2011). Third, the proportion of external debt to exports of merchandise and administrations can be determined as a pointer of viability (Reinhart \& Rogoff, 2010). This is due to an expanding debt-to-exports ratio, which can demonstrate whether the nation may have issues meeting its commitments later or not. Fourth, the proportion of aggregate unrewarded external debt to national salary can help pinpoint the debt threshold (Rahman, 2012). It provides evidence of the capacity to administer external debt by changing assets from the generation of domestic merchandise of products for the export market. Fifth, Net Present Value (NPV) of debt to current exports contrast the obligation weights with reimbursement capacity. The most rising and progressive governments endeavour to keep the total debt target proportion underneath $50 \%$ of their GDP in the medium term as an alluring arrangement per 
best practices. This is both for external and domestic debt. The NPV of the debtexport ratio, which ought to be underneath $150 \%$, or the NPV of debt-to-fiscal revenue ratio, which ought to be beneath $250 \%$, are incorporated under the HIPC Initiative of the World Bank and IMF (Bivens \& Irons, 2010). These two NPV ratios are key pointers of external debt sustainability as applied in the study by (Bivens \& Irons, 2010). Under this program, a nation's obligation status is viewed as unfeasible if debt-to-export levels are over a settled proportion of $150 \%$. However, nations that bear extremely open markets where elite dependence on external indicators may not satisfactorily mirror the fiscal weight of foreign debt (Okosodo \& Isedu (2011), and the debt-to-government incomes above around $250 \%$ are viewed as unfeasible. The debt-to-government incomes would speak to a nation's ability to reimburse if the exports were on the private records (Ali \& Mustafa, 2012), and it is inferred that the portions of debt service administration that are pertinent to social spending consider the association with the aggregate government incomes (Ezeabasili, Isu, \& Mojekwu, 2011)

It is commonly accepted that the pointers of sustainability over the long run would reply on the cooperation of a few essential variables. Development in finances, improvement in the nation's external segment, and the way the present shortfalls are financed are all examples of how a few essential variables can come together to function as a sustainability pointer (Michael \& Sulaiman, 2012). The last example raises critical issues with respect to the wellspring of external accounts from multilateral or bilateral sources (Murad \& Aziz, 2011). It also raises critical issues about the different types of outside inflows as portfolio streams, different 
invisibilities from hospitality or settlements, and non-obligation-making income streams, e.g. remote speculations (Murad \& Aziz, 2011).

\subsubsection{Liquidity Benchmarks}

Obligation pointers may depict a feasible pattern, but they sometimes create anxiety because obligation pointers are fundamentally affected by transient liquidity variables. Interim liquidity issues can escalate debt-servicing complications (Clements, Bhattacharya \& Nguyen, 2003). These complications can be touched off by factors such as the increment in global premium rates, a precipitous drop in export profit, an incremental increase in costs of imports such as oil, or the appreciation of the loan currency.

Many of the benchmarks specific to liquidity can be distinguished based on the following perspectives (Josic, 2013). First, the proportion of forex reserves to imports plays the role of an imperative pointer of liquidity, demanding that a nation keep up at any rate (Kumar, 2015). It is recommended that reserves are sufficient to compensate for no less than 3 months of imports (Kumar, 2015). Contingent upon the sort of conversion scale administrations and controls used, the reserve prerequisites can be huge. Second, the short-term debt reserves measure the susceptibility to the liquidity circumstance (Boboye \& Ojo, 2012). The debt-toreserves ratio is a valid pointer of vulnerability in the case of capital flight or reimbursements due to the transient debtor, because it is susceptible to speculative capital surges. Second, the interest remitances that determine the installments on all foreign debt could be secured by accessible reserves. Third, short-term debt, or total debt, was defined by Schclarek (2004) as the proportion of total external financing that is transient external debt (i.e., all debt with a outstanding maturity of lesser than 
twelve months). Short-term debt is viewed as a degree of liquidity weakness when there is a liquidity emergency.

Viewing debt in terms of maturity (short versus long term), composition (official versus private), and interest rates (fixed versus floating), as well as the scale of concession (grant elements), makes visible the underlying pointers affecting liquidity (Michael \& Sulaiman, 2012). Examples of these liquidity pointers can be seen in the budgetary emergencies in carribeans (1994), Southeast Asia (1997), and Russia (1998). These emergencies were solid indicators of liquidity issues as the regimes of these economic systems were compelled to renegotiate maturing, transient, foreignmoney-denominated financing under seriously worsening economic status (with higher interest rates, devalued national currencies, and fiscal susceptibility; Investment Frontier, 2013).

\subsubsection{Fiscal Benchmarks}

High debt levels, both local and external, ordinarily cause sympathy toward governments as they move assets far from improvement and towards debt servicing (Bivens \& Irons, 2010). According to Kasidi and Said (2013) and Clements et al. (2003), policymakers need to screen certain financial pointers of debt helplessness. First, policymakers should screen the debt service or fiscal revenue. Debt service is a proportion of fiscal revenue, and it functions as an index of how many budgetary assets are applied for national debt servicing, for all debts (Reinhart \& Rogoff, 2010). Second, policymakers should scrutinize the NPV of debt or fiscal revenue, which is a proportion of fiscal revenue that quantifies debt-servicing commitments in relation to government incomes (Shakar \& Aslam. 2015). This proportion also influences social spending (Shakar \& Aslam. 2015). These two metrics, debt service 
and NPV of debt, help policymakers determine benchmarks in the assessments due to their congruence in quantification and qualification of external debt.

Research indicates that benchmarking is a valuable and cooperative process among the debt administration institutions and policymakers. Debt administrators can work with government officials while there is fiscal policy planning. These two groups can work together to develop portfolio benchmarks and set debt targets. As observed in the case of Pakistan (Atique \& Malik, 2012) during a time of budget shortfalls, policymakers' chief consideration is developing national securities more appetizing to possible investment partners and choosing if to present new legal documents or not. However, countries may choose to lessen the status of debt that would cut the accessibility of recognized benchmarks during a time of spending plan surpluses (Michael \& Sulaiman, 2012).

Likewise, a given budgetary objectives such as a cap on the debt-to-GDP proportion, could restrict adaptability to benchmarket standards. Variegation of foreign borrowing in a a currency with low-interest to accomplish a acceptable interest expense may expand foreign currency risks. Thus, it is essential for a country's debt office to select the arrangement of portfolio benchmarks and debt targets that would provide the most variety (Sandleris, 2008). For example, the debt office would consider their country's debt market situations, financial position, government hazard preferences, and debt management objectives (Sandleris, 2008).

\subsubsection{Risk Management Benchmarks}

Debt administration capacity is concerned with the recognition, qualification, and administration of a debt portfolio and its effects (Stanescu, 2013). In a universe of 
floating currency exchange rate and interest rate, the debt service expenses vary together because of the changes in business sector costs (Ali \& Mustafa, 2012). Exchange risk emerges not only due to the alterations in the local currency against the loan currency but also to cross-currency developments in worldwide marketplaces. The latter can cause a substantial effect on debt servicing. For illustration, the increase of the value of the Japanese yen in comparison the United States Dollar can have an ascent in the US Dollar estimation of the foreign debt acquired in Japanese Yen (Schclarek, 2004).

The adverse outcomes are magnified when debt contracts at variable interest rates, for example, London Interbank Offered Rates (LIBOR) loans. A debt acquired at a variable rate of interest is liable to hazard as business sector premium rates boost (Arnone et al., 2010). Debt acquired at established interest rates carries a risk that there will be a significant decrease in business sector rates. It is recommended that the percentage of debt acquired at flexible interest rates be considered, and its vulnerability to mounting interest rates be observed and supervised.

Three essential risks related to standardised pointers can be advocated. First, the risk of disparity between budgeted and actual debt service quantifies the danger to the general society and debt portfolio on an income premise, as far as its effect on the real debt service as opposed to the planned debt service (Okosodo \& Isedu, 2011). Second, the risk of incorrectly rationing the segment of debt that is influenced by an ascent in the market rate of interest can be devastating, especially for foreign currency loans with floating rates (floating rate versus total debt). Third, the risk tolerance level as it relates to the potential absorptive limit of future increments in 
debt servicing can change because of adjustments in fundamental variables, such as trade and interest rates often change.

The interest rates and currency structure of debt and its developmental framework are significant elements of uncertainty in a debt portfolio (Bivens \& Irons, 2010). For instance, a regular benchmark would particularize not only the currency composition of the debt but also the currency of the debt, the length of time the debt was held, the scale of established and floating rate mechanisms, and the sorts of mechanisms used to acquire the debt (bank loans compared with bonds). It is in that regular benchmarking of national debt where it is critical to accurately assess any ideal currency portfolio involved and how closely it resembles the currency composition of reserves and export earnings (Arnone et al., 2010). It is recommended that regular benchmarking take into account the global premium rate benchmark, and this global premium rate may be some sort of subjective mean interest rate, OECD consensus rate, or the lending rates of the World Bank (Arnone et al., 2010).

The debt management protocol is a tool to select an ideal blend of settled and floating rate debt and to identify an ideal currency composition of the external debt portfolio. Regular inspection of the external debt portfolio ensures that periods of contraction (Ezeabasili et al., 2011) due to major cuts in trade rates and interest rates are handled appropriately. Periodic inspections also help identify extravagant foreign currency debt and when to undertake risk management protocols.

Periodic inspections allow debt supervisors to exploit a favorable forex and interest rate environment, in addition to arranging with the moneylenders for their 
prepayment to avoid the punishment of prepayment (Babu, 2014). It is imperative that the risk-oriented standards are designed using the risk apetite of the policymakers. The amount of risk tolerance in the government relies upon the amount of unpredictability that the country's financial position could maintain without endangering the macroeconomic protocols and budget targets.

\subsection{Previous Empirical Studies on Determinants of Debt}

Debt is a good financial option to facilitate economic growth as Oyejide, Soyode, and Kayode (1985) proclaimed. They stated that fast financial development presumes that a public venture might produce benefits well above the public funds available (Oyejide et al., 1985). Because of their perspective, economic ministries regularly borrow money to buttress public funds, which fills the nation's resource gap.

In more recent theory, scholars advocate for better understanding of external debt using a "dual gap" analysis (Nassar, Ajisafe, Fatokun, Soile \& Gidado, 2006). It explains that a nation's advancement has a venture element. For such a venture, domestic savings are not sufficient to safeguard growth. In an open economy, there must be the chance of acquiring the needed resources from overseas locations. A saving-investment gap exists when the applicable domestic savings fall short of the required level that is compulsory to accomplish the objective rates of development. Likewise, if there is an import condition greater than the current level of exports that is required to accomplish the desired development, then there is a foreign exchange gap with exports and import (Oke \& Boboye, 2012). Either way, nations are predispositioned to assume enormous foreign credits due to a saving-investment gap or a foreign exchange gap. 
The determinants of external debt revolve around the demand for funds by countries that have deficits in budgets. Alfonso (2003) indicated that the demand for debt finance makes it viable for countries with trade deficits so that they, in turn, can supply funds to other countries with trade deficits. It is the country-specific features that impact external debt that make it possible for one country to provide debt financing to another country in need of debt financing. The lending country, regardless of its external debt situation, still recognizes the economic value of the borrowing country. Under such circumstances, the benefit of both countries is assured, in spite of the disparity in magnitude and timing of the economic benefits. Secondly, the effectiveness of a country's economic and political policies has direct influence on the amount of debt that can be given or sought (Cumberworth $\&$ Milbourne, 1996). Countries with extensive foreign policies such as super powers rely on external debt to gain power and prominence in global politics. Countries such as the United States, China, and a number of European countries rely on provision of debt as a way of assisting growing economies achieve their goals (Bonga, Chirowa. Chiminya \& Strien, 2014).

Countries with similar economic, social, cultural, and political policies have a higher chance of relying on external debt (Bonga et al., 2014). In some instances, democracies have higher debts than aristocratic governments, since such governments do not share similar views with most of the developed countries. Countries with parliamentary systems have higher external debt due to lack of constraints in repayment across political systems as opposed to countries with presidential democratic systems. As a result, there are implications that debt provision targets countries where the benefits trickle to the citizens, as opposed to 
counties where political domination results in exploitation and plundering of the resources by the ruling class (Zeaiter, 2008). These debts are also tied to the specific requirements that promote the national agenda of the lending country. Lending countries provide debt financing to developing or developed countries as long as it is of strategic importance to growth and development of the lending country. The supply of external debt is sometimes based on the needs of the recipient country, making it possible for developing countries to benefit from the financing of operations in another country (Zeaiter, 2008). Although the process may run through regional cooperation organizations and may appear as though it is a sound financial decision, the key fact is that provision of external debt finances is not an indication of economic liberation or prowess (Lane, 2004).

The World Bank (1989) argued that the enormous debt package settlement created by LDCs depressed their development and structural arrangement. A corroborative study by Hassan, Hagen \& Haj (2005) determined whether the economic effects of external debt were mythical or realistic. The results included data from 82 countries with significant challenges in external debt over a 10-year period. The findings show that debt overhang was a reality and capable of compounding the economic challenges facing a country.

Abbas \& Christensen (2010) indicated that the overall effects were dependent on the existence of other forms and sources of debt. Economic empowerment effects crowd out other economic influences to reduce the overall effects of external debt. This was particularly true if the adverse outcomes are due to short-term economic climate factors, such as 2008-09 credit crunch. 
Mencinger, Aristovnik \& Verbic. (2014) focused on a growing level of external debt, such as the scenario experienced in Malaysia. The findings show that there was no statistical significant difference in the member countries in their ability to manage the growing external debt. However, the authors cautioned readers that there were no indications of the relativity of the increase or the relativity of the debt to the GDP. In their study, most of the participating countries in the region are developed.

Saibene \& Sicouri (2012) highlighted the effects of foreign-denominated debt on the economic growth of developing countries. The difference in the valence of currencies increased the sustainability of debt, especially if the currency in which the debt was denominated fluctuated more that the domestic currency and vice versa. The study indicated that developing countries with US Dollar-denominated debts faced significant challenges if they were not able to participate in international trade, since the fluctuations in exchange values compromised the ability of their domestic reserves to handle the debt.

The study by Loganathan et al. (2010) focused on analysis of the short- and longterm effects of macroeconomic indices and external debt in Malaysia. In the study, government revenue, government reserves, and balance of payment were the selected macroeconomic indicators. The application of time series analytics to annual data increased the precision of measurement of the real change in macroeconomic indicators between 1988 and 2008. The vector error correction approach was used for the short-term changes while cointegration method tested the long-term relationship. The results indicated that Malaysian external debt was sustainable eventually, based on the adjustments in the macroeconomic variables across the two decades. 
Benedict et al. (2014) examined the link between external debt in Nigeria its capacity to service in order to comprehend the sustainability, as well as identifying the determinants of external debt from 1986 to 2010. Cointegration test result indicated a long-run relationship exist between external debt and the independent variables. The study suggested that an indepth analysis should be carried out between the profitability in terms of social and economic aspects of all foreign debt funding projects. This is to secure the returns from the surplus of the principle repayment and interest.

Awan, Asghar \& Rehman, (2011) investigated the correlation between foreign debt and fiscal deficit, forex rate and terms of trade from 1974-2008 in Pakistan. The result from cointegration showed long-run relationships between forex rate and foreign debt; worsening of term of trade and external debt. However, there is no short-run link between the explanatory variables and foreign debt. Another study associate with Pakistan was by Batool \& Zulfiqar (2012). The explanatory variables were private investment, consumption, civic investment, borrowing rate, remittances and a dummy variable for governance. The study used OLS regression technique for the period 1973-2010. The findings indicates that private investment and consumption have a significant, direct relationships with external debt. Yet, a significant, inverse relationships with remittances and public investment. They agreed that a country should minimized external debt because it is dangerous for the growth of economy.

Cumberworth \& Milbourne (1996) indicated that external debt was closely linked to the economic model used by the country. A study on a number of OECD countries 
indicated that such open economic growth models lacked stringent restrictions on savings, population growth, and other forms of expenditure. These policies resulted in the weakening of asset positions. In order to bridge the gap, external debt becomes necessary. Lane (2004) indicated that such countries experience low productivity, low export penetration, and ineffective monetary policies that curtail the ability to accumulate assets. The weaknesses inherent in disjointed fiscal, monetary, and economic policies influences the propensity to choose an external debt as an alternative.

In a similar vein, Alfonso (2003) asserted that the availability of external debt was not the single most influential determinant of utilization of debt. Demand influences utilization more than supply, and most countries end up with highly costly debt due to the significantly restricted terms of the debt. Since most countries run on trade deficits, the availability of funds are diminished as debts are highly dependent on rationality and the viability of the returns. Consequently, the terms of the debt are restricted in ways that benefit the provider more than the recipient of the debt. In most cases, the limited supply results in unwarranted adjustments in the terms of repayment for the debt as indicated by Zeaiter (2008). Zeaiter (2008) linked the monstrous rates of non-payment to the characteristics of the debt and the subsequent debt requirements over any other cause of default or overhang.

External debt provides a supplementary source of capital for investment in important projects. In spite of the unreliability of foreign debt on economic development, most under-developed countries seem to increase their reliance on external debt over the years. Malaysia is part of the developing countries that are increasing relying on 
debt, in spite of debt service challenges. Based on the current trajectory, most of the countries are bound to continue their reliance on external debt. The selection of the variables is important to investigations of the determinants of external debt, since not all debt is directed to the same combination of economic elements. The disparities in developing countries imply that the destination of the capital from external debt varies over time. In most instances, changes in political systems resulted in changes in policies, which resulted in failure in the goal achievement. Instead of linking the external debt to a drop in economic performance, it is important to examine the underlying factors rather than the linear outcomes. As such, this study focuses on four determinants of external debt (GDP, exchange rates, recurrent expenditures, and capital expenditures). 


\section{Chapter 3}

\section{METHODOLOGY}

In this section, the econometric methodology that will be applied in the study will be discussed. Discussion will focus on identification of the tests that are used in the analyses described in the fourth chapter.

\subsection{Data Description}

Time series secondary data spanning from 1970 to 2013 will be used for this study. The data is sourced from the World Bank, IMF, and Malaysia's Ministry of Finance. This aim of the study is to indicate the link between the external debt of Malaysia and a number of macroeconomics factors. The macroeconomic factors include the gross domestic product (GDP), exchange rate (EXR), recurrent expenditure (REXP), and capital expenditure (CEXP).

The estimated model will rely on adoption of the cointegration and vector error correction model. The model will distinguish between long- and short-term effects and will then determine the causalities among the variables. For purposes of estimation, the relationship between the variables is outlined as follows;

$$
E D=f(G D P, E X R, R E X P, C E X P)
$$

where:

$$
\begin{aligned}
& \mathrm{ED}=\text { External debt, } \\
& \mathrm{GDP}=\text { Gross domestic product, }
\end{aligned}
$$




$$
\begin{aligned}
& \text { EXR }=\text { Exchange rate, } \\
& \text { REXP }=\text { Recurrent expenditure, } \\
& \text { CEXP = Capital expenditure. }
\end{aligned}
$$

Adding the error term, the explicit model becomes;

$$
\ln E D_{t}=\beta_{0}+\beta_{1} \ln G D P_{t}+\beta_{2} \ln E X R_{t}+\beta_{3} \ln R E X P_{t}+\beta_{4} \ln C E X P_{t}+\varepsilon_{t}
$$

The priori expectations of the explanatory variables are as follows

$$
\begin{aligned}
& \beta_{1}, \beta_{4}<0 \\
& \beta_{2}, \beta_{3}>0
\end{aligned}
$$

The coefficients $\beta_{1}, \beta_{2}, \beta_{3}$ and $\beta_{4}$ determine the impacts on external debt. It is expected that there should be inverse relationships between gross domestic product and external debt; capital expenditure and external debt. According to Benedict, Ehikioya \& Asin (2014), an increase in GDP results to a decrease in external debt due to the existence of domestically generated financial resources for utilization in the expenditure. Meanwhile, a study by Khan \& Villanueva (1991) stated that countries with an increasing amount of external debt comprehended such problem by increasing the investment ratios.

On the other hand, it is expected that there should be positive relationships between forex rate and external debt; recurrent expenditures and external debt. According to Awan, Asghar \& Rehman (2011) the value of external debt rises if the value of the currency of the debtor as weak in comparison with the creditor nation's currency. Thus, if exchange rate increases, external debt will increase. Moreover, Ribiero et al. 
(2012) stated, it is habitual for countries to borrow in order to finance recurrent expenditure. These recurrent expenditures are part of the total financial commitments of the government.

\subsection{Autocorrelation Functions (ACF)}

It was important to determine if the data is stationary before the regression analysis. If the ACF decreases slowly from 1 to 0 over a protracted period, then data is not stationary. Autocorrelation function can be estimated by using the formula given below;

$$
\begin{aligned}
& \rho_{\mathrm{k}}=\gamma_{\mathrm{k}} / \gamma_{0}=\text { Covariance at lag k/variance } \\
& \rho_{\mathrm{k}}=\left(\Sigma\left(\mathrm{Y}_{\mathrm{t}}-\overline{\mathrm{Y}}\right)\left(\mathrm{Y}_{\mathrm{t}+\mathrm{k}}-\overline{\mathrm{Y}}\right)\right) /\left(\Sigma\left(\mathrm{Y}_{\mathrm{t}}-\overline{\mathrm{Y}}\right)\right)^{2}
\end{aligned}
$$

\subsection{Unit Root Tests}

In order to investigate the link between macroeconomics factors and foreign debt in Malaysia while avoiding any spurious regressions, stationarity of the data has to be investigated. First, common practice was to investigate the time series variable by using a unit root test in each series prior to guesstimating any equation. If there was a unit root, then the series was named as nonstationary. Naturally, an estimation hinged on nonstationary factors may have caused spurious findings that were indicated with a high $\mathrm{R}^{2}$ and insignificant $t$ statistics.

To investigate the integration characteristics of the series, a number tests were used: Augmented Dickey Fuller (ADF), Phillip Perron (PP), and the Kwiatkowski, Phillips, Schmidt and Shinn (KPSS). ADF has three different specifications, the first eliminates both the inclination and the intercept (model 6a), second description comprises the intercept (model 6b), and the third measurement contains both the 
slope and the fixed term (model 6c). The study uses all three. ADF tests the null hypothesis that a series contains a unit root against the alternative hypothesis of stationarity.

$$
\begin{aligned}
& \Delta Y_{t}=\gamma Y_{t-1}+\alpha \sum \Delta Y_{t-1}+\varepsilon_{t} \\
& \Delta Y_{t}=\beta_{1}+\gamma Y_{t-1}+\alpha \sum \Delta Y_{t-1}+\varepsilon_{t} \\
& \Delta Y_{t}=\beta_{1}+\beta_{2} t+\gamma Y_{t-1}+\alpha \sum \Delta Y_{t-1}+\varepsilon_{t}
\end{aligned}
$$

$Y_{t}$ is the variable of interest, $\Delta$ is the differencing operator, in which $\Delta \mathrm{y}_{\mathrm{t}}=\mathrm{y}_{\mathrm{t}}-y_{t-1}, t$ is the time trend and $\varepsilon$ is the white noise residual of zero mean and constant variance. $\beta_{1}, \beta_{2}, \gamma$ and $\alpha$ are the parameters to be estimated. the null and alternative hypotheses in unit root tests are:

$$
\begin{aligned}
& \mathrm{H}_{0}: \gamma=0\left(Y t \text { has a unit root, or }{ }_{Y y} \text { is nonstationary }\right) \\
& \mathrm{H}_{1}: \gamma<0\left(_{Y t} \text { is stationary }\right)
\end{aligned}
$$

The regression model for the PP test (Phillips \& Perron, 1988) is:

$$
\Delta \mathrm{y}_{\mathrm{t}}=\beta_{0} \mathrm{D}_{\mathrm{t}}+\pi \mathrm{y}_{\mathrm{t}-1}+\mathrm{e}_{\mathrm{t}}
$$

The error term, $e_{t}$ may be heteroscedastic.

The PP test does not take care of serial correlation and heteroscedasticity in the regression model, but rather introduces new statistics $(t)$ in the error term. If these new test statistics are denoted by $\mathrm{B}_{\mathrm{a}}$ and $\mathrm{B}_{\mathrm{b}}$, then: 


$$
\begin{aligned}
& \mathrm{B}_{\mathrm{t}}=\left(\widehat{\sigma}^{2} / \hat{\lambda}^{2}\right)^{1 / 2} \cdot \mathrm{t}_{\pi=0}-(1 / 2)\left(\left(\hat{\lambda}^{2}-\widehat{\sigma}^{2}\right) /\left(\hat{\lambda}^{2}\right)\right) \cdot\left(\mathrm{T} \cdot \mathrm{SE}(\widehat{\pi}) / \widehat{\sigma}^{2}\right) \\
& \mathrm{B}_{\pi}=\mathrm{T} \widehat{\pi}^{2}-(1 / 2)\left(\mathrm{T}^{2} \cdot \mathrm{SE}(\widehat{\pi}) / \widehat{\sigma}^{2}\right)\left(\hat{\lambda}^{2}-\widehat{\sigma}^{2}\right)
\end{aligned}
$$

where

$$
\begin{aligned}
& \sigma^{2}=\lim \mathrm{T} \rightarrow \infty \mathrm{T}^{-1} \sum_{\mathrm{t}=1}^{\mathrm{T}} \mathrm{E}\left[\mathrm{u}_{\mathrm{t}}^{2}\right] \\
& \lambda^{2}=\lim \mathrm{T} \rightarrow \infty \sum_{\mathrm{t}=1}^{\mathrm{T}} \mathrm{E}\left[\mathrm{T}^{-1} \mathrm{~S}_{\mathrm{T}}^{2}\right]
\end{aligned}
$$

$B_{a}$ and $B_{b}$ are consistent variance parameter estimates. Here, $S T=\sum_{t=1}^{T} u_{t}$. The $H_{0}$ for PP test is the same as ADF test, that $\pi=1$.

While the ADF and PP tests have the $\mathrm{H}_{0}$ as the series having unit root, the KPSS test has $\mathrm{H}_{0}$ as the series being stationary. As outlined by Kwiatkowski, Phillips, Schmidt and Shin (1992) the regression test model is:

$$
\begin{aligned}
& y_{t}=\beta_{0} D_{t}+\mu_{t}+u_{t} \\
& \mu_{t}=\mu_{t-1}+\varepsilon_{t},
\end{aligned}
$$

where

$$
\varepsilon_{\mathrm{t}} \sim \mathrm{WN}\left(0, \sigma_{\varepsilon}^{2}\right)
$$

Both the null and alternative hypotheses in unit root tests are:

$$
\begin{aligned}
& \mathrm{H}_{0}: \sigma_{\varepsilon}^{2}=0 \\
& \mathrm{H}_{1:} \sigma_{\varepsilon}^{2}>0
\end{aligned}
$$

In contrast to the ADF and PP tests, the KPSS test does not have a $t$ statistic, but it gives a Lagrangian multiplier score instead to test whether $\sigma^{2}{ }_{\varepsilon}=0$. This multiplier is given by $\left(\mathrm{T}^{-2} \sum_{\mathrm{t}=1}^{\mathrm{T}} \hat{S}_{\mathrm{t}}^{2}\right) / \lambda$, and $\hat{S}_{\mathrm{t}}=\sum_{\mathrm{j}=1}^{\mathrm{t}} \hat{\mathrm{u}}_{\mathrm{j}}$, the rest of the assumptions are the same as 
the ADF and PP tests. The KPSS test statistic assumes that convergence to a model of normal Brownian motion is based on $D_{t}$, and not the coefficient values. After the unit root test was concluded, the test for cointegration was undertaken.

If the residual series is stationary, then standart regression procedure can be employed, if not first differencing will be performed.

\subsection{Cointegration Test}

After checking for the presence of unit roots in the factors, we proceeded to investigate the long-run relationship among variables. Johansen and Juselius (1990) cointegration test was used to investigate any possible long term relationship among nonstationary variables.

This technique is based on the direct examination of cointegrating vector autoregressive (VAR) illustration.

$$
\mathrm{Y}_{\mathrm{t}}=\alpha_{1} \mathrm{Y}_{\mathrm{t}-1}+\alpha_{2} \mathrm{Y}_{\mathrm{t}-2}+\ldots \ldots \ldots+\alpha_{\mathrm{k}} \mathrm{Y}_{\mathrm{t}-\mathrm{k}}+\varepsilon_{\mathrm{t}}
$$

$\mathrm{Y}_{\mathrm{t}}$ is $\mathrm{n} \times 1$ vector of $\mathrm{I}(1)$ endogenous variables (ED) and its elements in the VAR system while $\varepsilon$ t is a vector of white noise error terms. Based on the Granger representation theorem, if there was long-run link between variables, the vector error correction model (VECM) can be formed. Unlike VAR, this model was able to regulate the short-run relationship between variables. 


\subsection{Vector Error Correction Model}

The last step of the analysis entails the approximation of the short-run and long-run relationships between foreign debt and the descriptive variables. If the responses were significant in the short run only, then the impacts of explanatory variables were transitory. Consequently, if the effects were significant in the short-run and the longrun, then there was transitory and eternal effects. If there was cointegration (equilibrium relationship) among nonstationary variables there had to be an error correction representation (Engle \& Granger, 1987). Relationship between $\mathrm{Y}_{\mathrm{t}}$ and $\mathrm{X}_{\mathrm{t}}$ with an error correction specification was:

$$
\Delta \mathrm{Y}_{\mathrm{t}}=\beta_{0}+\beta_{1} \Delta \mathrm{X}_{\mathrm{t}}-\pi \hat{e}_{t-1}+\varepsilon_{\mathrm{t}}
$$

where $\beta_{1}$ would have the short-run result that measured the instant effect that a adjust in $\mathrm{X}_{\mathrm{t}}$ would have on adjustments in $\mathrm{Y}_{\mathrm{t}}$. Conversely, it was the change result and showed how fast the disequilibrium is being modified.

\subsection{Granger Causality Test}

In spite of the fact that regression analysis relates to the dependence of one factor to another, it does not automatically implies causation. According to the Granger representation theorem, once cointegration is established among variables, there will be a causality. The test procedure to examine the trend of causality among variables is illustrated below;

$$
\begin{aligned}
& Y_{t}=Y_{t-1}+X_{t-1}+u_{1 t} \\
& X_{t}=X_{t-1}+Y_{t-1}+u_{2 t}
\end{aligned}
$$


EViews software was used to conduct the econometric tests. 


\section{Chapter 4}

\section{EMPIRICAL ANALYSIS AND DISCUSSION OF THE RESULTS}

This section is a discussion of the findings from the empirical analysis. Descriptive statistics, unit root tests, cointegration analysis, vector error correction estimation, and Granger causality tests investigated the relationship among the variables used in our models outlined in Chapter 3.

\subsection{Descriptive Statistics}

These statistics of the variables in logarithmic forms are encapsulated in Table 1.

Table 1: Descriptive Analysis

\begin{tabular}{lllllll}
\hline Statistic & LNED & LNCEXP & LNEXR & LNGDP & LNREXP \\
Mean & 24.13295 & 9.267552 & 1.051514 & 25.66372 & 10.2146 \\
Median & 24.37239 & 9.303746 & 0.995788 & 25.68454 & 10.31315 \\
Maximum & 26.12594 & 10.87411 & 1.367207 & 27.61794 & 12.26089 \\
Minimum & 20.9004 & 6.586172 & 0.777894 & 23.29525 & 7.679251 \\
Std. Dev. & 1.515081 & 1.183575 & 0.185649 & 1.285624 & 1.281245 \\
Skewness & -0.652264 & -0.506687 & 0.396958 & -0.179419 & -0.242888 \\
Kurtosis & 2.360633 & 2.372407 & 1.760513 & 1.914814 & 2.170167 \\
Observations & 44 & 44 & 44 & 44 & 44 \\
\hline
\end{tabular}

Note: L denotes the natural logarithm.

As shown in Figure 2, there was an upward trend in all of the variables except the exchange rate when the nautral logarithm was applied. This may have indicated that nonstationarity existed when the variables did not oscillate around the mean. This 
indicated the existence of a unit root problem in time series data. Due to this, a formal unit root testing will be applied.
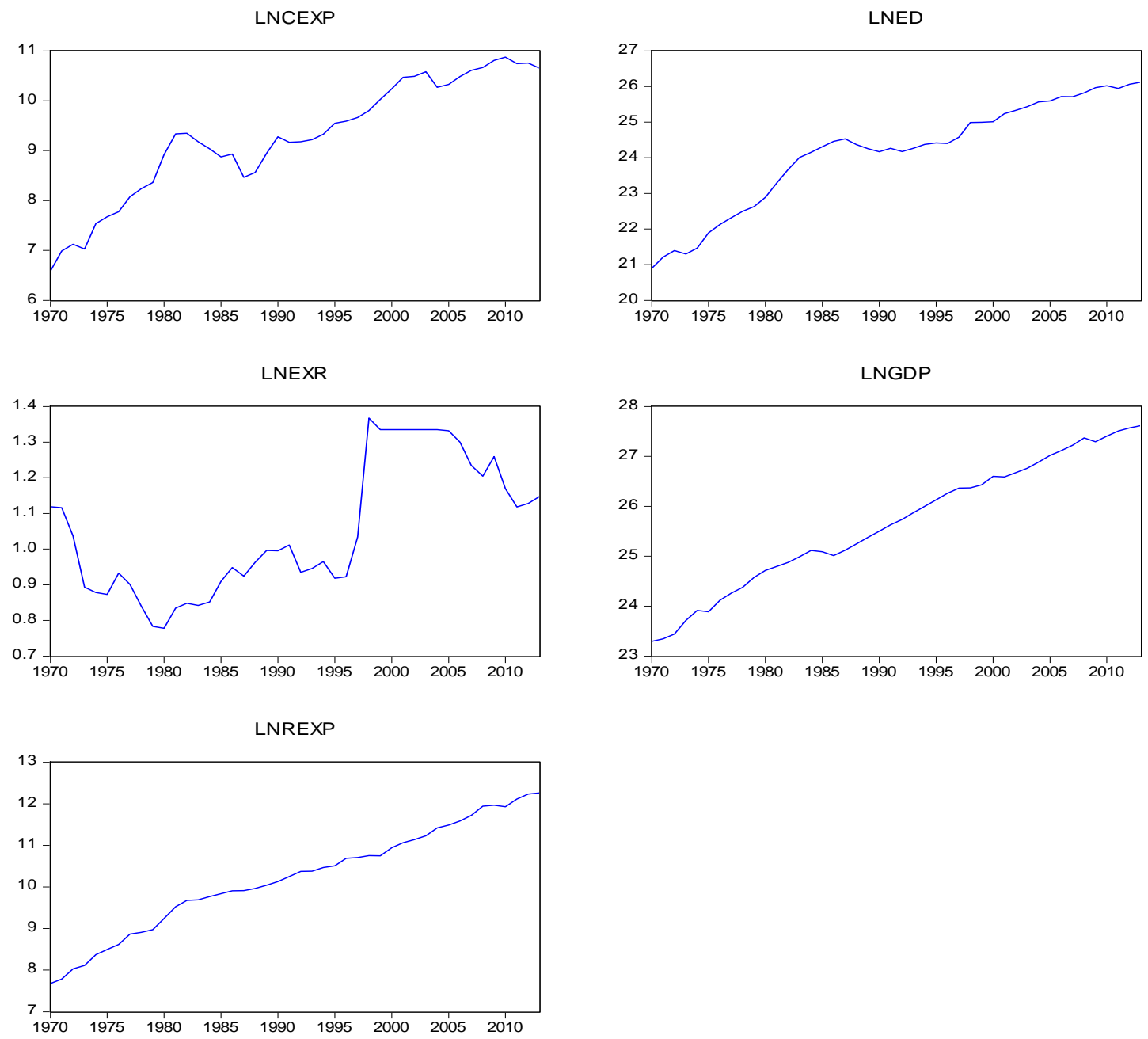

Figure 2. Time series of variables under natural logarithm

\subsection{ACF and PACF Results}

Table 2 indicates the results of ACF and PACF for 12 lags of each variable. The null hypothesis of the test is that there is no autocorrelation. The null hypothesis was rejected for all variables at level in 12 lags. The autocorrelation coefficient of the variables started at a significantly high value at lag 1 and declined very gradually. Thus, this may indicate the variables are nonstationary, because having unit root means persistent autocorrelation in all lags. In the case of level lag statics, having autocorrelation in 12 lags may specify nonstationary but may not necessarily confirm it. In case of variables at first difference, the null hypothesis in all variables except 
ED was failed to be rejected. This means that there is no unit root at first difference.

However, in the case of ED since the null hypothesis was rejected for all lags. This may indicate non stationarity and further test should be conducted to confirm. 
Table 2: ACF and PACF Results

\begin{tabular}{|c|c|c|c|c|c|c|c|c|c|c|}
\hline \multirow{2}{*}{$\begin{array}{l}\text { Statistics (Level) } \\
\underline{\text { Lag }}\end{array}$} & \multicolumn{2}{|c|}{ LnED } & \multicolumn{2}{|c|}{$\operatorname{lnGDP}$} & \multicolumn{2}{|c|}{$\operatorname{lnEXR}$} & \multicolumn{2}{|c|}{$\ln R E X P$} & \multicolumn{2}{|c|}{ InCEXP } \\
\hline & $\underline{\mathrm{AC}}$ & $\underline{\mathbf{P A C}}$ & $\underline{\mathrm{AC}}$ & $\underline{\mathbf{P A C}}$ & $\underline{\mathbf{A C}}$ & $\underline{\text { PAC }}$ & $\underline{\mathbf{A C}}$ & $\underline{\text { PAC }}$ & $\underline{\mathbf{A C}}$ & $\underline{\mathbf{P A C}}$ \\
\hline 1 & $0.919^{*}$ & $0.919^{*}$ & $0.929^{*}$ & $0.929^{*}$ & $0.927^{*}$ & $0.927^{*}$ & $0.919^{*}$ & $0.919^{*}$ & $0.907^{*}$ & $0.907^{*}$ \\
\hline 2 & $0.840^{*}$ & $-0.031^{*}$ & $0.855^{*}$ & $-0.061^{*}$ & $0.824^{*}$ & $-0.245^{*}$ & $0.836^{*}$ & $-0.059^{*}$ & $0.817^{*}$ & $-0.032^{*}$ \\
\hline 3 & $0.763^{*}$ & $-0.034^{*}$ & $0.780^{*}$ & $-0.045^{*}$ & $0.737^{*}$ & $0.100^{*}$ & $0.759^{*}$ & $-0.005^{*}$ & $0.728^{*}$ & $-0.041^{*}$ \\
\hline 4 & $0.672^{*}$ & $-0.127^{*}$ & $0.711^{*}$ & $0.001^{*}$ & $0.661^{*}$ & $0.006^{*}$ & $0.684^{*}$ & $-0.033^{*}$ & $0.625^{*}$ & $-0.133^{*}$ \\
\hline 5 & $0.580^{*}$ & $-0.069^{*}$ & $0.646^{*}$ & $-0.011^{*}$ & $0.576^{*}$ & $-0.187^{*}$ & $0.610^{*}$ & $-0.037^{*}$ & $0.541^{*}$ & $0.043^{*}$ \\
\hline 6 & $0.497^{*}$ & $0.008^{*}$ & $0.573^{*}$ & $-0.104^{*}$ & $0.481^{*}$ & $-0.027^{*}$ & $0.535^{*}$ & $-0.052^{*}$ & $0.464^{*}$ & $-0.012^{*}$ \\
\hline 7 & $0.420^{*}$ & $-0.017^{*}$ & $0.506^{*}$ & $0.007^{*}$ & $0.395^{*}$ & $-0.013^{*}$ & $0.466^{*}$ & $-0.013^{*}$ & $0.388^{*}$ & $-0.041^{*}$ \\
\hline 8 & $0.343^{*}$ & $-0.041^{*}$ & $0.443^{*}$ & $-0.021^{*}$ & $0.304^{*}$ & $-0.149^{*}$ & $0.404^{*}$ & $0.000^{*}$ & $0.327^{*}$ & $0.019^{*}$ \\
\hline 9 & $0.272^{*}$ & $-0.036^{*}$ & $0.381^{*}$ & $-0.038^{*}$ & $0.223^{*}$ & $0.059^{*}$ & $0.340^{*}$ & $-0.054^{*}$ & $0.273^{*}$ & $-0.004^{*}$ \\
\hline 10 & $0.203^{*}$ & $-0.047^{*}$ & $0.325^{*}$ & $0.005^{*}$ & $0.154^{*}$ & $-0.013^{*}$ & $0.276^{*}$ & $-0.047^{*}$ & $0.216^{*}$ & $-0.057^{*}$ \\
\hline 11 & $0.141^{*}$ & $-0.005^{*}$ & $0.274^{*}$ & $-0.009^{*}$ & $0.095^{*}$ & $-0.030^{*}$ & $0.223^{*}$ & $0.019^{*}$ & $0.173^{*}$ & $0.021^{*}$ \\
\hline 12 & $0.091^{*}$ & $0.019^{*}$ & $0.223^{*}$ & $-0.046^{*}$ & $0.031^{*}$ & $-0.068^{*}$ & $0.178^{*}$ & $0.008^{*}$ & $0.150^{*}$ & $0.081^{*}$ \\
\hline \multirow{2}{*}{$\begin{array}{l}\text { Statistics } \\
\text { (First Difference) }\end{array}$} & \multicolumn{2}{|c|}{$\operatorname{lnED}$} & \multicolumn{2}{|c|}{ InGDP } & \multicolumn{2}{|c|}{ InEXR } & \multicolumn{2}{|c|}{ InREXP } & \multicolumn{2}{|c|}{$\operatorname{lnCEXP}$} \\
\hline & $\underline{\mathrm{AC}}$ & PAC & $\underline{\mathrm{AC}}$ & $\underline{\mathbf{P A C}}$ & $\underline{\mathrm{AC}}$ & $\underline{\mathbf{P A C}}$ & $\underline{\mathrm{AC}}$ & PAC & $\underline{\mathrm{AC}}$ & $\underline{\text { PAC }}$ \\
\hline 1 & $0.427^{*}$ & $0.427^{*}$ & 0.044 & 0.044 & 0.224 & 0.224 & 0.065 & 0.065 & 0.225 & 0.225 \\
\hline 2 & $0.113^{* *}$ & $-0.085^{* *}$ & -0.176 & -0.178 & -0.083 & -0.140 & -0.113 & -0.117 & -0.041 & -0.096 \\
\hline 3 & $0.256^{*}$ & $0.295^{*}$ & 0.201 & 0.225 & -0.086 & -0.036 & 0.077 & 0.095 & 0.028 & 0.063 \\
\hline 4 & $0.263^{*}$ & $0.050^{*}$ & 0.044 & -0.020 & 0.079 & 0.106 & 0.279 & 0.259 & -0.021 & -0.050 \\
\hline 5 & $0.092^{*}$ & $-0.042^{*}$ & -0.061 & 0.015 & 0.073 & 0.015 & 0.036 & 0.020 & -0.113 & -0.096 \\
\hline 6 & $0.027^{* *}$ & $-0.029^{* *}$ & -0.043 & -0.086 & -0.098 & -0.117 & -0.079 & -0.037 & -0.011 & 0.037 \\
\hline 7 & $-0.059^{* *}$ & $-0.170^{* *}$ & -0.127 & -0.143 & 0.008 & 0.092 & 0.006 & -0.025 & -0.143 & -0.176 \\
\hline 8 & $-0.141^{* *}$ & $-0.113^{* *}$ & -0.037 & -0.028 & -0.064 & -0.118 & 0.155 & 0.077 & -0.014 & 0.083 \\
\hline 9 & $-0.278^{*}$ & $-0.259^{*}$ & -0.251 & -0.304 & -0.069 & -0.051 & -0.092 & -0.125 & 0.200 & 0.171 \\
\hline 10 & $-0.156^{*}$ & $0.104^{*}$ & -0.033 & 0.071 & -0.073 & -0.032 & 0.026 & 0.099 & -0.013 & -0.120 \\
\hline 11 & $0.026^{* *}$ & $0.165^{* *}$ & 0.177 & 0.096 & 0.012 & 0.021 & 0.010 & -0.029 & -0.088 & -0.027 \\
\hline 12 & $-0.073^{* *}$ & $0.009^{* *}$ & -0.062 & 0.032 & -0.037 & -0.084 & 0.021 & -0.012 & -0.091 & -0.136 \\
\hline
\end{tabular}

Note: ED represents external debt; GDP represents gross domestic product; EXR represents exchange rate; REXP represents recurrent expenditure; CEXP represents capital expenditure ${ }^{*},{ }^{* *}$, and ${ }^{* * *}$ denote rejection of the null hypothesis at the $1 \%, 5 \%$, and $10 \%$ levels, respectively. 


\subsection{Unit Root and Stationary Test Results}

To investigate the presence of stochastic nonstationarity in the series, the progression of integration of specific time series was established through the unit root tests. The tests of the stationarity of the variables adopted were ADF (Dickey \& Fuller, 1981), PP (Phillips \& Perron, 1988), and KPSS (Kwiatkowski et al., 1992). The summary of the unit root test can be seen in Table 3 below. Test findings reveal that all the series are nonstationary at their levels. We fail to reject the null hypothesis under ADF and PP, while we reject the null hypothesis under KPSS. Therefore, the outcomes of the unit root table indicates that all of the variables are integrated of order one, I(1). Thus, the use of contemporary econometric techniques such as OLS and its $t$ statistics and $F$ tests will lead to a spurious result (Choi, 2015). Instead, a cointegration test is better suited for the data. 
Table 3: ADF, PP Unit Root and KPSS Stationary Test Results

\begin{tabular}{|c|c|c|c|c|c|c|c|c|c|c|}
\hline Statistics (Level) & $\underline{\operatorname{lnED}}$ & Lag & $\underline{\operatorname{lnGDP}}$ & Lag & $\underline{\operatorname{lnEXR}}$ & lag & $\underline{\operatorname{lnREXP}}$ & $\underline{\text { lag }}$ & $\underline{\operatorname{lnCEXP}}$ & $\underline{\text { Lag }}$ \\
\hline$\tau \mathrm{T}(\mathrm{ADF})$ & $3.29^{* * *}$ & 4 & 2.10 & 0 & 2.36 & 0 & 2.46 & 4 & 2.32 & 1 \\
\hline$\tau \mu(\mathrm{ADF})$ & 1.77 & 1 & 1.78 & 0 & 1.18 & 0 & 2.02 & 0 & 1.75 & 1 \\
\hline$\tau(\mathrm{ADF})$ & 2.29 & 1 & 8.92 & 0 & 0.14 & 0 & 7.91 & 0 & 2.68 & 0 \\
\hline$\tau \mathrm{T}(\mathrm{PP})$ & 1.76 & 3 & 2.11 & 1 & 2.36 & 0 & 2.53 & 4 & 2.30 & 0 \\
\hline$\tau \mu(\mathrm{PP})$ & 2.44 & 3 & 1.78 & 0 & 1.18 & 0 & 2.13 & 4 & 2.31 & 1 \\
\hline$\tau(\mathrm{PP})$ & 3.51 & 4 & 8.52 & 3 & 0.17 & 1 & 6.98 & 3 & 2.32 & 2 \\
\hline$\tau \mathrm{T}(\mathrm{KPSS})$ & $0.15^{* *}$ & 5 & $0.41^{* * *}$ & 4 & $0.12^{* * * *}$ & 4 & $0.14^{* * *}$ & 5 & 0.09 & 4 \\
\hline$\tau \mu$ (KPSS) & $0.78^{*}$ & 5 & $0.84^{*}$ & 5 & $0.53^{* *}$ & 5 & $0.83^{*}$ & 5 & $0.79^{*}$ & 5 \\
\hline $\begin{array}{l}\text { Statistics } \\
\text { (First Difference) }\end{array}$ & $\underline{\operatorname{lnED}}$ & $\underline{\text { Lag }}$ & $\underline{\operatorname{lnGDP}}$ & Lag & InEXR & lag & InREXP & $\underline{\text { lag }}$ & $\underline{\operatorname{lnCEXP}}$ & Lag \\
\hline$\tau \mathrm{T}(\mathrm{ADF})$ & $4.31^{*}$ & 0 & $6.45^{*}$ & 0 & $5.01^{*}$ & 0 & 2.44 & 3 & $5.21^{*}$ & 0 \\
\hline$\tau \mu(\mathrm{ADF})$ & $4.09^{*}$ & 0 & $6.041^{*}$ & 0 & $5.03^{*}$ & 0 & 2.48 & 3 & $5.08^{*}$ & 0 \\
\hline$\tau(\mathrm{ADF})$ & $3.11^{*}$ & 0 & 1.46 & 2 & $5.09^{*}$ & 0 & 1.45 & 3 & $4.59^{*}$ & 0 \\
\hline$\tau \mathrm{T}(\mathrm{PP})$ & $4.36^{*}$ & 1 & $6.48^{*}$ & 2 & $4.94^{*}$ & 5 & $6.18^{*}$ & 2 & $5.18^{*}$ & 3 \\
\hline$\tau \mu(\mathrm{PP})$ & $4.06^{*}$ & 2 & $6.03^{*}$ & 3 & $4.95^{*}$ & 5 & $5.84^{*}$ & 0 & $5.08^{*}$ & 2 \\
\hline$\tau(\mathrm{PP})$ & $3.08^{*}$ & 1 & $2.60^{* *}$ & 4 & $5.02^{*}$ & 5 & $2.72^{*}$ & 1 & $4.59^{*}$ & 1 \\
\hline$\tau \mathrm{T}(\mathrm{KPSS})$ & 0.09 & 3 & 0.04 & 0 & $0.12^{* *}$ & 2 & $0.14^{* *}$ & 3 & 0.08 & 0 \\
\hline$\tau \mu(\mathrm{KPSS})$ & 0.32 & 4 & 0.29 & 2 & 0.15 & 2 & 0.35 & 1 & 0.27 & 1 \\
\hline
\end{tabular}

Note: ED represents external debt; GDP represents gross domestic product; EXR represents exchange rate; REXP represents recurrent expenditure; CEXP represents capital expenditure. $\tau_{\mathrm{T}}$ represents the most general model with a drift and trend; $\tau_{\mu}$ is the model with a drift and without trend; $\tau$ is the most restricted model without a drift and trend. Numbers in brackets are lag lengths used in ADF test to remove serial correlation in the residuals. When using PP test, numbers in brackets represent Newey-West Bandwith (as determined by Bartlett-Kernel). Both in ADF and PP tests, unit root tests were performed from the most general to the least specific model by eliminating trend and intercept across the models. ${ }^{*},{ }^{* *}$, and ${ }^{* * *}$ denote rejection of the null hypothesis at the 1\%,5\%, and 10\% levels, respectively. Tests for unit roots have been carried out in E-VIEWS 7.0. 


\subsection{Cointegration Results}

The Johansen Cointegration test was applied to nonstationary variables that are integrated into the same order as described in Johansen \& Juselius (1990). In order to proceed with cointegration, first the finding of optimal lag selection is performed because it is a decisive aspect of empirical research since all inference are based on the correct chosen of this parameter. By using Akaike, Schwarz and Hannan-Quinn information criterions, the optimal lag selection turns out to be one as seen in table 4 .

Table 4: VAR Lag order selection criteria results

\begin{tabular}{cccc}
\hline$\underline{\text { Lag }}$ & $\underline{\mathrm{AIC}}$ & $\underline{\mathrm{SC}}$ & $\underline{\mathrm{HQ}}$ \\
0 & 0.917782 & 1.126 .755 & 0.993878 \\
1 & $\mathbf{- 1 0 . 8 8 7 2 1 *}$ & $\mathbf{- 9 . 6 3 3 3 8 1 *}$ & $\mathbf{- 1 0 . 4 3 0 6 4}$ \\
2 & -1.057 .379 & -8.275 .099 & -9.736 .735 \\
3 & -1.071 .086 & -7.367 .308 & -9.493 .325 \\
\hline Note: * denotes lag order selected by the criterion
\end{tabular}

Next, since the five variables of LNED, LNCEXP, LNEXR, LNGDP and LNREXP were found as I(1). The result of the cointegration is shown in Table 5 by using lag 1 .

Table 5: Cointegration test results

\begin{tabular}{|c|c|c|c|c|}
\hline Null hypothesis & Eigenvalue & $\underline{\text { Trace statistics }}$ & $\frac{5 \% \text { critical }}{\text { value }}$ & $\frac{1 \% \text { critical }}{\text { value }}$ \\
\hline $\mathrm{H}_{0}: \mathrm{r}=0$ & 0.553573 & $69.57079^{*}$ & $\overline{68.52}$ & $\overline{76.07}$ \\
\hline $\mathrm{H}_{0}: \mathrm{r} \leq 1$ & 0.342632 & 35.69865 & 47.21 & 54.46 \\
\hline $\mathrm{H}_{0}: \mathrm{r} \leq 2$ & 0.237011 & 18.07919 & 29.58 & 35.65 \\
\hline
\end{tabular}

Note: $*$ denotes rejection of the null hypothesis at $5 \%$ critical value level

Based on the findings, the first null hypothesis was rejected at level since the trace statistic was larger than the critical level at alpha of 5\%. Meaning one cointegrating vector can be observed. Thus, indicating that a long-run relationship could be 
inferred between LNED and, LNCEXP, LNEXR, LNGDP, and LNREXP. Moreover, the normalized cointegrating coefficients is stated in table 6 .

Table 6: Normalized cointegrating coefficients results

\begin{tabular}{lcccc}
\hline$\underline{\operatorname{lnED}}$ & $\underline{\operatorname{lnEXR}}$ & $\underline{\operatorname{lnGDP}}$ & $\underline{\operatorname{lnREXP}}$ & $\underline{\operatorname{lnCEXP}}$ \\
1.000000 & -0.086271 & 0.782960 & -0.861093 & -0.979664 \\
& $(0.25133)$ & $(0.31983)$ & $(0.34866)$ & $(0.13550)$ \\
\hline
\end{tabular}

Note: Standard error in parantheses

Therefore, the long-run cointegrating vector can be written as;

$$
\begin{aligned}
\mathrm{LNED}= & 0.0862 \ln \mathrm{nXR}-0.7829 \operatorname{lnGDP}+0.861 \operatorname{lnREXP}+0.9796 \operatorname{lnCEXP} \\
& +\varepsilon_{t}
\end{aligned}
$$

The signs of all parameters in the long-run cointegrating vector do comply with the priori expectations except for $\operatorname{lnCEXP}$ which shows a direct relationship with external debt. However, the significance of the coefficients can only be determined in the following step. Nonetheless, the presence of one cointegation vector between the nonstationary variables make it possible to estimate VECM and to capture the dynamic adjustment.

\subsection{Vector Error Correction Model Results}

Based on the results of the Johanssen cointegration model, a long-run relationship was established between foreign debt and the independent factors. At this stage, the estimation of the long-term coefficients for the external debt model as indicated in equation 2 in Chapter 3 (Engle \& Granger, 1987). 
Table 7: VECM results

\begin{tabular}{|c|c|c|c|c|}
\hline Result & Variable & Coefficient & Standard Error & $t$ Statistic \\
\hline Speed of adjustment & $\Delta \operatorname{lnED}$ & -0.258 & 0.089 & -2.875 \\
\hline \multirow[t]{4}{*}{ Short run relationship } & $\Delta \ln \operatorname{EXR}(-1)$ & 0.581 & 0.350 & 1.605 \\
\hline & $\Delta \operatorname{lnGDP}(-1)$ & 0.225 & 0.287 & 0.722 \\
\hline & $\Delta \ln \operatorname{REXP}(-1)$ & 0.065 & 0.251 & -0.231 \\
\hline & $\Delta \operatorname{lnCEXP}(-1)$ & 0.261 & 0.117 & -0.746 \\
\hline \multirow{4}{*}{ Long run relationship } & $\operatorname{lnEXR}(-1)$ & -0.086 & 0.251 & -0.343 \\
\hline & $\operatorname{lnGDP}(-1)$ & $0.783 *$ & 0.319 & 2.448 \\
\hline & $\operatorname{lnREXP(-1)}$ & $-0.861 *$ & 0.349 & -2.469 \\
\hline & $\operatorname{lnCEXP}(-1)$ & $-0.979 *$ & 0.135 & -7.230 \\
\hline
\end{tabular}

Note: $*$ indicates the coefficient is significant

By including intercept, the long-run cointegrating vector becomes;

$$
\begin{aligned}
\mathrm{LNED} & =26.238+0.0862 \ln \mathrm{nXR}-0.7829 \ln \mathrm{GDP}+0.861 \ln \mathrm{REXP} \\
& +0.9796 \ln \mathrm{CEXP}+\varepsilon_{t}
\end{aligned}
$$

Based on Table 7, ED convergence to its long-run equilibrium level by $26 \%$ speed of adjustment every year by the contribution of CEXP, EXR, GDP, and REXP. It was statistically significant at $\alpha=0.01$.

Unfortunately, no significant short-run relationship can be observed in the results.

Meanwhile, long-run relationships can be interpreted as, if EXR increases by 1\%, ED will increase by $0.086 \%$. If GDP increases by $1 \%$, ED will decrease by $0.783 \%$. A $1 \%$ increase in REXP leads to a $0.861 \%$ increase in ED. Lastly, a $1 \%$ increase in CEXP leads to a $0.979 \%$ increase in ED. 
Based on the priori expectations, only two variables have significant and correct signs. Those two are GDP and REXP. GDP has a significant, inverse relationship with ED while REXP has a significant, direct relationship with ED. Although EXR is insignificant, but it proves to have a direct relationship with ED. However, CEXP showed that it has a significant, direct relationship with ED, eventhough economic theory indicates it should have an inverse relationship.

\subsection{Granger Causality Test Results}

Table 8 indicates the results of the Pairwise Granger Causality Tests for the study. The Granger causality test was applied under the VECM results as indicated in the methodology section of Chapter 3 and discussed in Sysoev \& Sysoeva (2015). Based on the results, the null hypothesis was the indicator for non-causality between the dependent and independent variable. Because there was statistical significance between the variables, we rejected the null hypothesis and stated that the independent variable is Granger-cause of the dependent variable.

Table 8: Granger Causality Test results

\begin{tabular}{|c|c|c|c|c|c|c|}
\hline $\begin{array}{l}\text { Dependent } \\
\text { Variables }\end{array}$ & $\Delta \ln E D$ & $\Delta \operatorname{lnCEXP}$ & $\Delta \ln R E X P$ & $\Delta \operatorname{lnEXR}$ & $\Delta \operatorname{lnGDP}$ & Inferences \\
\hline$\Delta \ln E D$ & - & 0.25879 & 1.71000 & $4.14970^{* * *}$ & 0.20572 & $\Delta \ln E D \geq \Delta \ln E X R$ \\
\hline$\Delta \operatorname{lnCEXP}$ & $27.5466^{*}$ & - & 0.1197 & $3.90003^{* * *}$ & 0.15055 & $\begin{array}{l}\Delta \operatorname{lnCEXP} \geq \Delta \ln E D, \\
\Delta \ln C E X P \geq \Delta \ln E X R\end{array}$ \\
\hline$\Delta \ln R E X P$ & $4.76526^{* *}$ & 0.79693 & - & $4.26148^{* *}$ & 0.04004 & $\begin{array}{l}\Delta \ln R E X P \geq \Delta \ln E D, \\
\Delta \ln R E X P \geq \Delta \ln E X R\end{array}$ \\
\hline$\Delta \operatorname{lnEXR}$ & 0.34701 & 1.05560 & 0.61151 & - & 0.21385 & - \\
\hline$\Delta \operatorname{lnGDP}$ & $4.53058^{* * *}$ & $6.11882^{* *}$ & $10.2191^{*}$ & $5.50632^{* *}$ & - & $\begin{array}{l}\Delta \operatorname{lnGDP} \geq \Delta \ln E D, \\
\Delta \operatorname{lnGDP} \geq \Delta \operatorname{lnCEXP}, \\
\Delta \operatorname{lnGDP} \geq \Delta \operatorname{lnREXP}, \\
\Delta \operatorname{lnGDP} \geq \Delta \operatorname{lnEXR}\end{array}$ \\
\hline
\end{tabular}

Note: $*, * *$, and $* * *$ denotes statistically significant at $1 \%, 5 \%$, and $10 \%$ levels, respectively.

The Granger causality test is performed in order to determine the direction of causality in the variables of the estimated model. The null hypothesis of the model is 
that there is no causal relationship between the variables. The data in Table 6 shows that there are one-way causality relationships running from CEXP to ED and EXR, from ED to EXR, from REXP to ED, and from GDP to ED, CEXP, EXR and REXP. This study concluded that a movement in CEXP preceded the movements in ED and EXR. A movement in ED preceded a movement in EXR. A movement in REXP preceded a movement in ED. A movement in GDP preceded the movements in ED, CEXP, EXR and REXP. Furthermore, no bidirectional relationship was seen between the variables. 


\section{Chapter 5}

\section{CONCLUSIONS AND RECOMMENDATION}

As economic theory posits, determinants of external debt are closely linked to changes in economic growth and ensure its sustainability through quality capital expenditures. As stated in the literature, the fiscal authorities normally deploy external debt for investments and infrastructure development of a country for the debt to be sustainable. In this study, the dependent variable was ED (external debt), the independent variables were GDP (gross domestic product), EXR (exchange rate), REXP (recurrent expenditure) and CEXP (capital expenditure). Five tests were run including autocorrelation tests that were targeted to determine whether the data was stationary. The unit root tests, the Augmented Dickey Fuller (ADF), Phillip Perron (PP), and the Kwiatkowski, Phillips, Schmidt and Shinn (KPSS) were performed. Johansen Cointegration test and vector error correlation model estimation were conducted. Finally, the Granger causality test was utilized to test the existence of causation and the direction of the relationship between the variables that were used in the study. These statistics were designed to test the size and path of the link between the variables.

The Autocorrelation test indicated that there is no autocorrelation if the null hypothesis is failed to be rejected. Results of the test is, null hypothesis was rejected for all 12 lags in level form. For first difference, the null hypothesis was failed to be rejected for all the variables except ED. Therefore, unit root testing was carried out. 
The results of the unit root tests showed that the data is stationary in first difference. Next, cointegration test indicated that there is a maximum of one cointegrating vector under the optimal lag selection of one. The VECM test was performed to determine the short-run and long-run relationships between the dependent variable and explanatory variables. The results indicated that there is no significant, short-run relationship but there are long-run relationships as proven by cointegration results. The Granger causality test indicated that external debt only preceed a movement in one of the explanatory variables, which is the exchange rate. In addition, each one of the explanatory variables (except exchange rate) do preceed a movement in external debt. Overall, only uni-directional relationships can be observed in the Granger causality test.

Two out of the four expectations were met in a significant manner through the longrun relationships. The government manage to reduce external debt by increasing GDP. But, the government increases capital expenditure by increasing external debt. This goes against the economic theory. In order to sustain debt, a government should increase capital expenditure in order to repay external debt. In addition, the possibility of sustaining the debt can be contradicted due to the fact that recurrent expenditure is relied on external debt. Hence, Malaysia should find an alternative to gain money for recurrent expenditure instead of taking it out of the external debt fund. Based on the four explanatory variables, it is clear that Malaysian government rely on GDP for the repayment of external debt.

Against this backdrop, there is a need for the government to put in place policies capable of ensuring quality deployment of external debts through budgeting rules like the fiscal responsibility act that is being used in successful economies. It is well 
known that Malaysia is a one-product economy. Any dip in the international price of crude oil affects the treasury functions of the state. To this end, it is expedient for the government to build in modern project management methods into the budgeting systems to ensure high capital budget implementation rate. Malaysia's institutions like the Public Procurement Bureau must be reformed and strengthened to create an enabling platform for nations to allow the private sector take the driving seat in infrastructure development and investment through Public Private Partnership (PPP) models.

To address the need for creative budgeting using PPP models, Malaysia needs to deemphasize the role of governments in the markets, diversify the economy, and build strong institutions to bring forth faster development. Our results show a case for building strong institutions because of the humongous effect of corrupt tendencies in budget planning and execution affairs of the State. Although linear links exist between the changes in GDP and the external debt to categories of expenditure, the nominal financial measures are not sufficiently indicative of the challenges facing the country in servicing the debt.

One sure way to eradicate corruption in Malaysia is to remove the subsidy in certain industries to enhance competitiveness in production. Subsidies in developed countries are not used to augment consumption but to augment production. Subsidies are better suited for manufacturers, farmers, and industrialists. In addition to other forms of capital and recurrent expenditure, the country should focus on enhancing the value of its current through increased regional and global trade. The present system of subsidies if not well-channeled greatly distorts the incentive to produce by citizens. It instead engenders rent-seeking behaviors as the present system shows. 
Ending petroleum product subsidy will greatly allow private investors to come into that sector increasing the availability of products, ensuring citizen welfare, and saving the much needed foreign reserves.

Finally, the surreptitious way of concealing extra budgetary items and recurrent expenditures through creative accounting methods outside of parliament-approved procedures should be eradicated. The intense corruption and lack of professionalism in the management of public resources result in huge and sustained financial leakage in the economy. As a result, this corruption obscures information and makes it more difficult to arrive at reliable statistics. It also reduces the effectiveness of strategies at the national and local government levels. This happens because the system greatly hides the true extent of the external debt portfolio and its use. This leads to erroneous and deceitful economic forecasts, which continues to hinders Malaysia's economy. 


\section{REFERENCES}

Abbas, S. M., \& Christensen, J. (2010). The role of domestic debt markets in economic growth: an empirical investigation for low income countries and emerging markets. IMF Staff Papers, 57(1), 209-255.

ADB \& ADBI. (2009). Infrastructure for a Seamless Asia. Tokyo: Asian Development Bank.

Ajayi, S. L. (1991). Macroeconomic Approach to External Debt-The case of Nigeria (No. RP_08).

Akram, N. (2015). Is public debt hindering economic growth of the Philippines? International Journal of Social Economic, 42(3), 202-221.

Alfonso, A. (2003). Understanding the determinants of sovereign debt ratings: Evidence for the two leading agencies. Journal of Economics and Finance, $27(1), 56-74$

Ali, R., \& Mustafa, U. (2012). External debt accumulation and its impact on economic growth in Pakistan. The Pakistan Development Review, 51(4), 79-96. 
Arestis, P, \& Sawyer, M. (2009). Path dependency and demand-supply interations in macroeconomics analysis. Path Dependency and Macroeconomics, Basingstoke, Palgrave Macmillan, 1-36.

Ariff, M., \& Abubakar, S. Y. (1999). The Malaysian financial crisis: economic impact and recovery prospects. The Developing Economies, 37(4), 417-438.

Arnone, M., Bandiera, L., \& Presbitero, A. F. (2010). External debt sustainability: theory and empirical evidence. Retrieved on September $16^{\text {th }} 2015$ from http://core.ac.uk/download/pdf/9311316.pdf.

Athukorala, P. (2010). Malaysian Economy in Three Crises. Working Paper No. 2010/12, Crawford School of Economics and Government, Arndt-Corden Department of Economics.

Atique, R., \& Malik, K. (2012). Impact of domestic and external debt on the economic growth in Pakistan. World Applied Sciences Journal, 20(1), 120129.

Awan, R. U., Anjum, A., \& Rahim, S. (2015). An econometric analysis of determinants of external debt in Pakistan. British Journal of Economics, Management and Trade, 5(4), 1-10.

Awan, A., Asghar, N., \& Rehman, H. (2011), The impact of exchange rate, fiscal deficit and terms of trade on external debt of Pakistan: A cointegration and 
causality analysis. Australian Journal of Business and Management Research, 1(3), 10-24.

Babu, J. O. (2014). External debt and economic growth in the East Africa community. African Journal of Business Management, 8(21), 1011-1018.

Batool, S. A., \& Zulfiqar,S. (2012). What determines external debt? Empirical evidence from Pakistan. The Business \& Management Review, 3(1), 263.

Benedict, I., Ehikioya, I. L., \& Asin, O. M. (2014). Determinants and sustainability of external debt in a deregulated economy: A Cointegration analysis from Nigeria (1986-2010). American International Journal of Contemporary Research, 4(6), 201-214.

Bivens, J., \& Irons, J. (2010). Government debt and economic growth. Retrieved April 6, 2015, from Economic Policy Institute: http://www.epi.org/publication/bp271

Boboye, A. L., \& Ojo, O. N. (2012). Effects of external debt on economic growth and development of Nigeria. International Journal of Business and Social Sciences, 3(12), 297-304.

Bonga, W. G., Chirowa, F., Chiminya, J., \& Strien, M. V. (2014). World dedollarisation: economic implication of de-dollarisation in Zimbabwe (introduction of special coins). Available at SSRN 2534972. 
Borensztein, E. (1991). Will debt reduction increase investment? Finance and Development, 28(1), 25-27.

Bullow, J., \& Rogoff, K. (1989). Sovereign debt: is to forgive and forget? The American Economic Review, 79(1), 43-50.

Carter, C., \& Harding, A. (2010). Special Economic Zones in Asian Market Economics. Routledge.

Choi, I. (2015). Almost all About Unit Roots:Foundation, Developments and Applications.UK: Cambridge University Press.

Clements, B., Bhattacharya, R., \& Nguyen, T. Q. (2003). External Debt, Public Investment, and Growth in Low-Income Countries. IMF.

Collignon, S. (2012). Europe's Debt Crisis, Coordination Failure and International Effects. Working Paper No. 370.

Cumberworth, M., \& Milbourne, R. (1996). External debt and liabilities: Evidence from a Cross Section of Countries. Economic Record, 72(218), 201-213.

Dickey, D. A., \& Fuller, W. A. (1981). Likelihood ratio statistics for autoregressive time series with a unit root. Econometrica: Journalof the Econometric Society, 49(4), 1057-1072. 
Dyson, K. (2014). States, Debt, and Power: 'Saints and Sinners' in European History and Integration. OUP Oxford.

Edes, B. W., \& Morgan, P. J. (2014). Managing fiscal sustainability and aging in emerging asia. Public Policy Review, 10(2), 319-348.

Edo, S. E. (2002). Financial management analysis of contributions of external and domestic factors to foreign debt accumulation in Nigeria and Morocco. Journal of Financial Management \& Analysis, 15(2), 69.

Elmendorf, D. W., \& Mankiw, N. G. (1998).Government Debt. Working Paper No. w6470.

Engle, R., \& Granger, C. (1987). Cointegration and error correction representation: estimation and testing. Econometrica, 55(2), 251-276.

Ezeabasili, V. N., Isu, H. O., \& Mojekwu, J. N. (2011). Nigeria's external debt and economic growth: an error correction approach. International Journal of Business and Management, 6(5), 156.

Greene, J., \& Villanueva, D. (1991). Private investment in developing countries. IMF Staff Papers, 38(1), 33-58.

Hassan, Z. (2002). The 1997-1998 Financial Crisis in Malaysia: causes, responses and results. Islamic Economies Studies, 9(2), 1-16. 
Hassan, M., Hagen, A., \& Haj, M. (2005). Is the impact of foreign loans on the economic growth of severely indebted underdeveloped countries a myth or reality? Corroborative evidence. Journal of Economics and Economic Education Research, 6(2), 61.

Hayati, A. R. (2012). The relationship between budget deficit and economic growth from Malaysia's perspective. International Proceedings of Economics Development and Research, 38, 54-58.

Investment Frontier. (2013). 7 Countries with debt ceilings or limits. page. investment frontier. October 8. 2013. Retrieved April 10, 2015, from Investment Frontier: http://www.investmentfrontier.com/2013/10/08/7countries-with-debt-ceilings-or-limits.

Johansen, S., \& Juselius, K. (1990). Maximum likelihood estimation and inferences on cointegration-with applications to the demand for money. Oxford Bulletin of Economics and Statistics, 52(2), 169-210.

Josic, H. (2013). Comparative analysis of external debt indicators in Croatia and south-eastern european countries. Ekonomska Misao I Praska, 22(1), 197220.

Kasidi, F., \& Said, A. M. (2013). Impact of external debt on economic growth: a case study of Tanzania. Advances in Management and Applied Economics, $3(4), 59-82$. 
Khan, M. S., \& Villanueva, D. (1991). Macroeconomic Policies and Long-Term Growth: A Conceptual and Empirical Review. IMF African Economic Research Consortium Special Paper 13.

Krugman, P. R. (1988). Financing vs. Forgiving a Debt Overhang.Working Paper No. 2486.

Kumar, R. R. (2015). Nexus between tourism earnings and the economic growth: a study of Malaysia. Quality and Quantity, 49(3), 1101-1120.

Kumar, M., McLambo, K., \& Savvides, A. (1996). Determinants of Private Investment in Sub Saharan Africa: An Empirical Investigation. IMF Working Paper.

Kwiatkowski, D., Phillips, P. C., Schmidt, P., \& Shin, Y. (1992). Testing the null hypothesis of stationarity against the alternative of a unit root. Journal of Econometrics, 54(1), 159- 178.

Lane, P. (2004). Empirical perspectives on long-term external debt. Topics in Macroeconomics, 4(1), 1-15.

Loganathan, N., Sukemi, M. N., \& Sanusi, N. A. (2010). External debt and macroeconomics performance in Malaysia: sustainable or not? Global Economy and Finance Journal, 3(2), 122-132. 
Maddala, G. S., \& Kim, I. (1999). Unit Roots, Cointegration and Structural Change. UK: Cambridge University Press.

Mankiw, N. G., Romer, D., \& Weil, D. N. (1990). A contribution to the empirics of economic growth. Working Paper No. w3541. National Bureau of Economic Research.

Meesook, K. (2001). Malaysia: From Crisis to Recovery (Vol. 207). International Monetary Fund.

Memon, P. A., Rus, R. B., \& Ghazali, Z. B. (2014). Firm and macroeconomic determinants of debt: Pakistan evidence. Social and Behavioural Sciences, 172(1), 200-207.

Mencinger, J., Aristovnik, A., \& Verbic, M. (2014). The impact of growing public debt on economic growth in the European Union. Amfiteatru Economic. $16(35), 403-414$

Michael, O., \& Sulaiman, L. A. (2012). External debt, economic growth and investment in Nigeria. European Journal of Business and Management, $4(11), 67-75$

Morgan, P. J., \& Kawai, M. (2013). Long-term issues for fiscal sustainability in emerging Asia. Public Policy Review, 9(4), 751- 770. 
Murad, W., \& Aziz, F. (2011). Macroeconomic effects of external debt and debt service on economic growth in Pakistan (a case study of Pakistan 19702010). Interdisciplinary Journal of Contemporary Research in Business, 3(4), $1-17$.

Nassar, A. F., Ajisafe, R. A., Fatokun, O., Soile, I., \& Gidado, O. K. (2006). External debt and foreign private investment in Nigeria: a test for causality. Africa Economic and Business Review, 4(1), 48-63

Ogunmuyiwa, M. (2011). Does external debt promote economic growth in Nigeria? Current Research Journal of Economic Theory, 3(1), 29-35.

Oke, M. O., \& Boboye, 1. (2012). Effect of external debt on economic growth and development of Nigeria. International Journal of Business and Social Science, 3(12), 297-304.

Okosodo, L. A. \& Isedu, M. O. (2011). The impact of external debt burden on the growth of agricultural and manufacturing sectors in the Nigerian economy (1980-2008). Interdisciplinary Journal of Contemporary Research in Business, 3(2), 1-15.

Oyejide, T. A., Soyode, A., \& Kayode, M. O. (1985). Nigeria and the IMF. Ibadan: Heinemann Educational Books (Nigeria)

Panizza, U., \& Presbitero, A. F. (2014). Public debt and economic growth: is there a causal effect. Journal of Mcroeconomics 41, 21-41. 
Pattillo, C., Poirson, H., \& Ricci, L. (2004). What are the Channels through which external Debt Affects Growth? Retrieved on September 16th 2015 from https://www.imf.org/external/pubs/ft/wp/2004/wp0415.pdf

Pattillo, C. (2002). External debt and growth. Retrieved on September 16th 2015 from http://www.imf.org/external/pubs/ft/fandd/2002/06/pattillo.html.

Phillips, P., \& Perron, P. (1988). Testing for a unit root in time series regression. Biometrika, 75(2), 335-346.

Rahman, N. (2012). How federal government's debt affect the level of economic growth? International Journal of Trade, Economics and Finance, 3(4), 323326.

Reinhart, C. M., \& Rogoff, S. K. (2010). Growth in a time of debt. American Economic Review, 100(2), 573-578.

Ribiero, M. P., Villafuente, M., Baunsgaard, T., \& Richmond, C. J. (2012). Fiscal Frameworks for Resource Rich Developing Countries. International Monetary Fund.

Saibene, G., \& Sicouri, S. (2012). Effects of currency devaluations on the economic growth in developing countries: the role of foreign currencydenominated debt. Atlantic Economic Journal, 40(2), 191-209. 
Sandleris, G. (2008). Sovereign default: information, investment and credit. Journal of International Economics, 76(2), 267-275.

Schclarek, A. (2004). Debt and Economic Growth in Developing and Industrial Countries. Working Paper 2005/34. Lund University Department of Economics.

Shabbir, S. (2009). Does external debt affect economic growth: evidence from developing countries. Retrieved on September 16th 2015 from http://aysps.gsu.edu/sites/default/files/documents/ECON_MA_shabbirS.pdf

Shakar, S. A., \& Aslam. M. (2015). Foreign direct investment, human capital and economic growth in Malaysia. Journal of Economic Cooperation and Development, 36(1), 103-132.

Stanescu, M. C. (2013). The effects of the economic crisis on the public debt of the member states of European Union. Romanian Economic and Business Review, 8(1), 7-18.

Sysoev, I. V., \& Sysoeva, M. V. (2015). Detecting changes in coupling with granger causality method time series with fast transient processes. Physica D, 309(1), 9-19.

The Malaysian Insider, (2015). Malaysia economy stable despite 50\% debt to GDP ratio. Retrieved on September 16th 2015 from http://www.themalaysianinsider.com/malaysia/article/malaysian-economystable-despite-50-debt-to-gdp-ratio-says-chua-bernama 
Were, M. (2001). The Impact of External Debt on Economic Growth in Kenya: An Empirical Assessment. WIDER Discussion Paper No 116, United Nations University.

Zakaria, Z., Hussein, Z. H., Noordin, N. B., \& Sawal, B. M. (2010). Financial Crisis of 1997/1998 in Malaysia: causes, impacts and recovery plans. Voice of Academic, 5(1), 1-18.

Zeaiter, H. F. (2008). Determinants of Soverreign-Debt Default in Developing Countries. The University of Wisconsin-Milwaukee. 


\section{APPENDICES}

\section{APPENDIX A: ACF and PACF}

Level form

Sample: 19702013

Included observations: 44

\begin{tabular}{|c|c|c|c|c|c|c|c|c|}
\hline \multicolumn{2}{|c|}{ Autocorrelation } & \multicolumn{3}{|c|}{ Partial Correlation } & \multirow{2}{*}{$\frac{A C}{0.919}$} & \multirow{2}{*}{$\frac{\text { PAC }}{0.919}$} & \multirow{2}{*}{$\begin{array}{l}\text { Q-Stat } \\
39.785\end{array}$} & \multirow{2}{*}{$\frac{\text { Prob }}{0.000}$} \\
\hline 1 & & 1 & ב & 1 & & & & \\
\hline 1 & $\square$ & 1 & 1 & 2 & 0.840 & -0.031 & 73.819 & 0.000 \\
\hline 1 & & 1 & 1 & 3 & 0.763 & -0.034 & 102.54 & 0.000 \\
\hline 1 & $\square$ & 1 당 & 1 & 4 & 0.672 & -0.127 & 125.40 & 0.000 \\
\hline 1 & $\square$ & 10 & 1 & 5 & 0.580 & -0.069 & 142.83 & 0.000 \\
\hline 1 & $\square$ & 1 & 1 & 6 & 0.497 & 0.008 & 156.01 & 0.000 \\
\hline 1 & $\square$ & 1 & 1 & 7 & 0.420 & -0.017 & 165.65 & 0.000 \\
\hline 1 & $\square$ & 1 & 1 & 8 & 0.343 & -0.041 & 172.28 & 0.000 \\
\hline 1 & $\square$ & 1 & 1 & 9 & 0.272 & -0.036 & 176.56 & 0.000 \\
\hline 1 & $\square^{\prime}$ & 1 & 1 & 10 & 0.203 & -0.047 & 179.00 & 0.000 \\
\hline 1 & $\square$ । & 1 & 1 & 11 & 0.141 & -0.005 & 180.22 & 0.000 \\
\hline 1 & 01 & 1 & 1 & 12 & 0.091 & 0.019 & 180.74 & 0.000 \\
\hline
\end{tabular}

First Difference form

Sample: 19702013

Included observations: 43

\begin{tabular}{|c|c|c|c|c|c|c|c|c|}
\hline Autocorr & relation & Partial Co & rrelation & & $A C$ & PAC & Q-Stat & Prob \\
\hline 1 & $\square$ & I & $\square$ & 1 & 0.427 & 0.427 & 8.4024 & 0.004 \\
\hline 1 & ? & 14 & 1 & 2 & 0.113 & -0.085 & 9.0025 & 0.011 \\
\hline & $\square$ । & $1=$ & $\square$ & 3 & 0.256 & 0.295 & 12.162 & 0.007 \\
\hline 1 & $\square$ & 1 & 1 & 4 & 0.263 & 0.050 & 15.597 & 0.004 \\
\hline 1 & ? & 1 & 1 & 5 & 0.092 & -0.042 & 16.028 & 0.007 \\
\hline I & 1 & 1 & 1 & 6 & 0.027 & -0.029 & 16.066 & 0.013 \\
\hline 1 & 1 & 1 당 & 1 & 7 & -0.059 & -0.170 & 16.251 & 0.023 \\
\hline 10 & I & 12 & 1 & 8 & -0.141 & -0.113 & 17.357 & 0.027 \\
\hline$\square$ & 1 & 1 & 1 & 9 & -0.278 & -0.259 & 21.762 & 0.010 \\
\hline 1 등 & 1 & 1 & 1 & 10 & -0.156 & 0.104 & 23.194 & 0.010 \\
\hline 1 & 1 & 1 & $\exists$ । & 11 & 0.026 & 0.165 & 23.236 & 0.016 \\
\hline 14 & 1 & 1 & 1 & 12 & -0.073 & 0.009 & 23.565 & 0.023 \\
\hline
\end{tabular}




\section{APPENDIX B: Johansen Cointegration}

VAR Lag Order Selection Criteria

Endogenous variables: LNED LNEXR LNGDP LNREXP

LNCEXP

Exogenous variables: $\mathrm{C}$

Sample: 19702013

Included observations: 41

\begin{tabular}{ccccccc}
\hline \hline Lag & LogL & LR & FPE & AIC & SC & HQ \\
\hline \hline 0 & -13.81454 & NA & $1.72 \mathrm{e}-06$ & 0.917782 & 1.126755 & 0.993878 \\
1 & 253.1879 & $455.8578^{*}$ & $1.30 \mathrm{e}-11^{*}$ & $-10.88721^{*}$ & $-9.633381^{*}$ & $-10.43064 *$ \\
2 & 271.7628 & 27.18273 & $1.88 \mathrm{e}-11$ & -10.57379 & -8.275099 & -9.736735 \\
3 & 299.5727 & 33.91458 & $1.91 \mathrm{e}-11$ & -10.71086 & -7.367308 & -9.493325 \\
\hline \hline
\end{tabular}

* indicates lag order selected by the criterion

LR: sequential modified LR test statistic (each test at 5\% level)

FPE: Final prediction error

AIC: Akaike information

criterion

SC: Schwarz information

criterion

HQ: Hannan-Quinn information criterion

1CointegratingEquation(s): Log likelihood 259.0216

Normalized cointegrating coefficients (standard error in parentheses)

$\begin{array}{cccrc}\text { LNED } & \text { LNEXR } & \text { LNGDP } & \text { LNREXP } & \text { LNCEXP } \\ 1.000000 & -0.086271 & 0.782960 & -0.861093 & -0.979664 \\ & (0.25133) & (0.31983) & (0.34866) & (0.13550)\end{array}$


Sample (adjusted): 19722013

Included observations: 42 after adjustments

Trend assumption: Linear deterministic trend

Series: LNED LNEXR LNGDP LNREXP LNCEXP

Lags interval (in first differences): 1 to 1

\begin{tabular}{ccccc}
\hline \hline $\begin{array}{c}\text { Hypothesized } \\
\text { No. of CE(s) }\end{array}$ & Eigenvalue & $\begin{array}{c}\text { Trace } \\
\text { Statistic }\end{array}$ & $\begin{array}{c}\text { 5 Percent } \\
\text { Critical Value Critical Value }\end{array}$ \\
\hline \hline None $*$ & 0.553573 & 69.57079 & 68.52 & 76.07 \\
At most 1 & 0.342632 & 35.69865 & 47.21 & 54.46 \\
At most 2 & 0.237011 & 18.07919 & 29.68 & 35.65 \\
At most 3 & 0.135740 & 6.717676 & 15.41 & 20.04 \\
At most 4 & 0.013965 & 0.590665 & 3.76 & 6.65 \\
\hline \hline
\end{tabular}

Trace test indicates 1 cointegrating equation(s) at the 5\% level Trace test indicates no cointegration at the $1 \%$ level $*(* *)$ denotes rejection of the hypothesis at the 5\%(1\%) level 
Vector Error Correction Estimates Date: 12/01/15 Time: 12:24

Sample (adjusted): 19722013

Included observations: 42 after adjustments

Standard errors in ( ) \& t-statistics in [ ]

\begin{tabular}{|c|c|c|c|c|c|}
\hline Cointegrating Eq: & CointEq1 & & & & \\
\hline $\operatorname{LNED}(-1)$ & 1.000000 & & & & \\
\hline $\operatorname{LNEXR}(-1)$ & $\begin{array}{r}-0.086271 \\
(0.25133) \\
{[-0.34325]}\end{array}$ & & & & \\
\hline LNGDP(-1) & $\begin{array}{c}0.782960 \\
(0.31983) \\
{[2.44801]}\end{array}$ & & & & \\
\hline $\operatorname{LNREXP(-1)}$ & $\begin{array}{r}-0.861093 \\
(0.34866) \\
{[-2.46972]}\end{array}$ & & & & \\
\hline LNCEXP(-1) & $\begin{array}{c}-0.979664 \\
(0.13550) \\
{[-7.23021]}\end{array}$ & & & & \\
\hline $\mathrm{C}$ & -26.25837 & & & & \\
\hline Error Correction: & D(LNED) & D(LNEXR) & $\mathrm{D}(\mathrm{LNGDP})$ & D(LNREXP) & $\mathrm{D}(\mathrm{LNCEXP})$ \\
\hline CointEq1 & $\begin{array}{r}-0.257917 \\
(0.08971) \\
{[-2.87498]}\end{array}$ & $\begin{array}{r}-0.020172 \\
(0.06223) \\
{[-0.32414]}\end{array}$ & $\begin{array}{r}-0.085855 \\
(0.05892) \\
{[-1.45716]}\end{array}$ & $\begin{array}{c}0.020410 \\
(0.05630) \\
{[0.36255]}\end{array}$ & $\begin{array}{c}0.037091 \\
(0.14917) \\
{[0.24866]}\end{array}$ \\
\hline $\mathrm{D}(\operatorname{LNED}(-1))$ & $\begin{array}{r}-0.041200 \\
(0.22281) \\
{[-0.18491]}\end{array}$ & $\begin{array}{r}-0.084505 \\
(0.15456) \\
{[-0.54673]}\end{array}$ & $\begin{array}{r}-0.072399 \\
(0.14633) \\
{[-0.49475]}\end{array}$ & $\begin{array}{c}0.198674 \\
(0.13982) \\
{[1.42090]}\end{array}$ & $\begin{array}{r}-0.028345 \\
(0.37047) \\
{[-0.07651]}\end{array}$ \\
\hline $\mathrm{D}(\operatorname{LNEXR}(-1))$ & $\begin{array}{c}0.581019 \\
(0.35013) \\
{[1.65943]}\end{array}$ & $\begin{array}{c}0.389793 \\
(0.24288) \\
{[1.60485]}\end{array}$ & $\begin{array}{r}-0.263183 \\
(0.22995) \\
{[-1.14450]}\end{array}$ & $\begin{array}{r}-0.474782 \\
(0.21972) \\
{[-2.16084]}\end{array}$ & $\begin{array}{c}0.534228 \\
(0.58217) \\
{[0.91764]}\end{array}$ \\
\hline D(LNGDP(-1)) & $\begin{array}{c}0.225039 \\
(0.28702) \\
{[0.78404]}\end{array}$ & $\begin{array}{r}0.143766 \\
(0.19911) \\
{[0.72205]}\end{array}$ & $\begin{array}{r}-0.125889 \\
(0.18851) \\
{[-0.66782]}\end{array}$ & $\begin{array}{c}0.555757 \\
(0.18012) \\
{[3.08549]}\end{array}$ & $\begin{array}{r}1.670459 \\
(0.47724) \\
{[3.50022]}\end{array}$ \\
\hline D(LNREXP(-1)) & $\begin{array}{c}0.065494 \\
(0.25133) \\
{[0.26059]}\end{array}$ & $\begin{array}{r}-0.040214 \\
(0.17434) \\
{[-0.23066]}\end{array}$ & $\begin{array}{r}-0.342752 \\
(0.16506) \\
{[-2.07650]}\end{array}$ & $\begin{array}{r}-0.256747 \\
(0.15772) \\
{[-1.62789]}\end{array}$ & $\begin{array}{r}-0.272973 \\
(0.41789) \\
{[-0.65322]}\end{array}$ \\
\hline D(LNCEXP(-1)) & $\begin{array}{r}-0.054634 \\
(0.11715) \\
{[-0.46637]}\end{array}$ & $\begin{array}{r}-0.060584 \\
(0.08127) \\
{[-0.74550]}\end{array}$ & $\begin{array}{r}-0.039725 \\
(0.07694) \\
{[-0.51631]}\end{array}$ & $\begin{array}{r}0.176364 \\
(0.07352) \\
{[2.39901]}\end{array}$ & $\begin{array}{r}0.291832 \\
(0.19479) \\
{[1.49821]}\end{array}$ \\
\hline $\mathrm{C}$ & 0.097346 & 0.006792 & 0.164584 & 0.036054 & -0.078952 \\
\hline
\end{tabular}




\begin{tabular}{|c|c|c|c|c|c|}
\hline & $\begin{array}{r}(0.06441) \\
{[1.51128]}\end{array}$ & $\begin{array}{r}(0.04468) \\
{[0.15201]}\end{array}$ & $\begin{array}{r}(0.04230) \\
{[3.89049]}\end{array}$ & $\begin{array}{r}(0.04042) \\
{[0.89195]}\end{array}$ & $\begin{array}{r}(0.10710) \\
{[-0.73717]}\end{array}$ \\
\hline R-squared & 0.543018 & 0.109104 & 0.236135 & 0.453075 & 0.361065 \\
\hline Adj. R-squared & 0.464678 & -0.043621 & 0.105187 & 0.359317 & 0.251533 \\
\hline Sum sq. resids & 0.377187 & 0.181509 & 0.162696 & 0.148539 & 1.042802 \\
\hline S.E. equation & 0.103811 & 0.072014 & 0.068180 & 0.065146 & 0.172610 \\
\hline F-statistic & 6.931581 & 0.714385 & 1.803273 & 4.832364 & 3.296439 \\
\hline Log likelihood & 39.37092 & 54.73114 & 57.02894 & 58.94069 & 18.01551 \\
\hline Akaike AIC & -1.541472 & -2.272911 & -2.382331 & -2.473366 & -0.524548 \\
\hline Schwarz SC & -1.251861 & -1.983300 & -2.092719 & -2.183754 & -0.234937 \\
\hline Mean dependent & 0.117002 & 0.000757 & 0.101703 & 0.106631 & 0.087168 \\
\hline S.D. dependent & 0.141885 & 0.070493 & 0.072076 & 0.081389 & 0.199517 \\
\hline \multicolumn{2}{|c|}{ Determinant resid covariance (dof adj.) } & $7.53 \mathrm{E}-12$ & & & \\
\hline \multicolumn{2}{|c|}{ Determinant resid covariance } & $3.03 \mathrm{E}-12$ & & & \\
\hline \multicolumn{2}{|l|}{ Log likelihood } & 259.0216 & & & \\
\hline \multicolumn{2}{|c|}{ Akaike information criterion } & -10.42960 & & & \\
\hline \multicolumn{2}{|l|}{ Schwarz criterion } & -8.774675 & & & \\
\hline
\end{tabular}




\section{APPENDIX D: Granger Causality}

Pairwise Granger Causality Tests

Sample: 19702013

Lags: 1

\begin{tabular}{|c|c|c|c|}
\hline Null Hypothesis: & Obs & F-Statistic & Prob. \\
\hline LNGDP does not Granger Cause LNED & \multirow[t]{2}{*}{43} & 4.53058 & 0.0395 \\
\hline LNED does not Granger Cause LNGDP & & 0.20572 & 0.6526 \\
\hline LNEXR does & \multirow[t]{2}{*}{43} & 0.3 & 0.5591 \\
\hline LNED does not Granger Cause LNEXR & & 4.14970 & 0.0483 \\
\hline LNCEXP do & \multirow[t]{2}{*}{43} & 27. & 5.E-06 \\
\hline LNED does not Granger Cause LNCEXP & & 0.25879 & 0.6137 \\
\hline LNREXP do & \multirow[t]{2}{*}{43} & 4.7 & 0.0350 \\
\hline LNED does not Granger Caus & & 1.71000 & 0.1985 \\
\hline LNEXR & \multirow[t]{2}{*}{43} & & 0.6463 \\
\hline LNGDP does not Granger Cause LNEXR & & 5.50632 & 0.0240 \\
\hline LNCEXP does not Gra & \multirow[t]{2}{*}{43} & 0.15 & 0.7001 \\
\hline LNGDP does not Granger Cause LNCEXP & & 6.11 & 0.0177 \\
\hline LNREXP does $n$ & \multirow[t]{2}{*}{43} & 0.04 & 0.8424 \\
\hline LNGDP does not Granger Cause LNREXP & & 10.2191 & 0.0027 \\
\hline $\mathrm{LNCE}$ & \multirow[t]{2}{*}{43} & & 0.0552 \\
\hline LNEXR does not Granger Cause LNCEXP & & 1.05560 & 0.3104 \\
\hline LNREXP does not Granger Cause LNEXR & \multirow[t]{2}{*}{43} & 4.26 & 0.0455 \\
\hline LNEXR does not Granger Cause LNREXP & & 0.61151 & 0.4388 \\
\hline t Granger Cause LNCEXP & \multirow[t]{2}{*}{43} & 0.79 & 0.3774 \\
\hline LNCEXP does not Granger Cause LNREXP & & 2.52797 & 0.1197 \\
\hline
\end{tabular}

